\title{
EDITORIAL
}

\section{The changing landscape of JIBS authorship}

\author{
John Cantwell ${ }^{1}$, \\ Anke Piepenbrink ${ }^{2}$, \\ Pallavi Shukla ${ }^{1}$ and \\ Alexandra $\mathrm{Vo}^{1}$ \\ ${ }^{1}$ Department of Management and Global \\ Business, Rutgers University, Newark, NJ, USA; \\ ${ }^{2}$ ESC Rennes School of Business, Rue Robert \\ d'Arbrissel, 35065 Rennes, France

\section{Correspondence:} \\ John Cantwell, Department of Management \\ and Global Business, Rutgers University, \\ Newark, NJ, USA. \\ Tel: 973-353-5050; \\ e-mail: cantwell@business.rutgers.edu
}

\begin{abstract}
In this study, we examine the landscape of JIBS authorship over time to assess: (1) the accessibility of JIBS to new contributors, and (2) the diversity of authors contributing to JIBS. Our analysis of author data from 1972 to 2014 shows that JIBS is becoming more accessible, as indicated by the high and sustained proportion of first-time contributors to the journal. This is also evident from the recent decline in the share of authors with multiple past JIBS publications. With regard to diversity, our findings show that JIBS has a much wider geographic scope of authors on its landscape in comparison to previous decades. This may be attributed partly to increasing travel and communication in scholarly communities, and partly to the increased migration of scholars in the recent decades. Our analysis of migration patterns of JIBS authors suggests that about $51 \%$ of prominent international business scholars are employed outside their country of birth. Of the $49 \%$ employed in their country of birth, $12 \%$ are return migrants. In our sample, China, South Korea and Canada have the highest number of returnees. The USA, the UK, Germany, the Netherlands and China have the highest number of natives, whose country of birth, country of PhD-granting institution and country of university affiliation are identical. Journal of International Business Studies (2016) 47, 749-777. doi: 10.1 057/s4 1267-016-0004-5
\end{abstract}

Keywords: research collaboration; geographic diversity; migration; mobility; first-time author

\section{INTRODUCTION}

The Academy of International Business (AIB), which is the leading association of international business (IB) scholars, has 3,188 members in 88 countries around the world, according to the AIB website as of February 2016. The number of new members joining AIB annually has grown almost tenfold since 1980 (see Table A1 in the Appendix for details). This growth has been accompanied by an increase in the geographic spread of the AIB membership as well (see Figure A1 and Table A2 in the Appendix for details). Just as the membership of the AIB has become more diverse and geographically dispersed, so has the authorship landscape of JIBS - the official publication of the AIB. In 1972, JIBS published 10 articles by authors, all but one of whom were located in the US. In 2014, by comparison, JIBS published 54 articles by authors located in 28 countries. This gives us some indication of how the composition of JIBS authorship has changed in the last few decades, which have also seen a rising trend in the number of articles published (see Figure A2 and Table A3 in the Appendix for details).

Is JIBS equally accessible to first-time authors as it is to well renowned, more established scholars? As the Editor-in-Chief of 
$J I B S$, the first author has encountered this question at conferences and meetings numerous times, and therefore this study was long overdue. To seek an answer to this question, we assess the accessibility of JIBS along two dimensions - (1) first-time authorships and (2) multiple repeat authorships. When a scholar who has never published in JIBS publishes for the first time in JIBS, he or she is referred to as a first-time author. A repeat author, on the other hand, is one with multiple JIBS publications. With regard to first-time authorships, in this investigation, we examine the percentage of first-time contributors to the journal from 1995 to 2014 using author data from 1972 to 1994 as the inherited stock of authors that have published in JIBS. To further assess the openness of JIBS, we examine how the share of articles by repeat authors has varied over time. Since JIBS has been striving to be open and accessible to new scholars and new disciplines, we examine the trend in the number of multiple repeat authors over time. To this end, we recorded the number of previous publications in JIBS for each author-year pair for all authors since 1980.

The last two decades have witnessed an increase in international scholarly travel and communication enabled by technologies with faster connectivity, both virtual and physical, between regions that span the globe. This has facilitated, among other things such as a rise in the quality and quantity of business schools worldwide, an increase in international co-authorship not only in the social sciences, but also in the sciences, arts and humanities (Choi, 2012). Many formerly unknown authors have thus emerged on the authorship landscape of JIBS. As JIBS publishes insightful, impactful, and innovative research on firms that cross political boundaries and often, although not always, operate in different institutional environments, we examine how international is the research community that dedicates its efforts to this field. Two decades have passed since a similar question was tackled by Thomas, Shenkar, and Clarke (1994), and so we seek to reassess where we stand in terms of the geographic spread of JIBS authors. Thus in this study, we examine the diversity of JIBS contributors in terms of their geographic dispersion across the JIBS landscape. For this purpose, we analyze JIBS author data from 1972 to 2014 to determine the geographic location of authors who collaborated on research projects. We use the university affiliation of an author to determine his or her geographic location.
Lower cost of global communications and lower cost of travel has facilitated human mobility across long distances and has enabled temporary and permanent people flows. Increased human mobility, in turn, has enabled scientists to expand their human and social capital through participation in international knowledge networks (Edler, Fier, \& Grimpe, 2011). International Business (IB) scholars, like natural scientists, partly due to the nature of the business they are in, tend to be quite mobile and this makes them more likely to form collaborations across the globe. To improve our understanding of this phenomenon, we examine the migration patterns of JIBS contributors. For this purpose, we use biographical information of the authors who published in JIBS between and including 2008 to 2014 . To map the migration patterns of a scholar, we use his or her country of birth, country of PhD-granting institution and university affiliation (as given on the publication). We use the terms country of birth and country of origin interchangeably.

Our analysis shows that JIBS has become more open and has a much wider geographic scope of authors. By open, we mean that it is as accessible to new authors as it is to established or already recognized authors. Our analysis of JIBS author data reveals that roughly $60 \%$ of authors publishing in JIBS are first-time contributors. We also find a discernible declining trend in the percentage of multiple repeat authors from 2010 onwards, suggesting that in the term of the current editorial team since 2011 the journal has become relatively more accessible to new scholars. Consistent with the findings of other studies that have focused on the science and engineering ( $S \& E$ ) disciplines, we also find that there has been an increase in the number of authors per article published in JIBS. With regard to the diversity of JIBS contributors in terms of their geographic dispersion, we find that the research community of JIBS is more geographically dispersed worldwide than ever before. Authors from the United States continue to be the largest contributing group to JIBS. In the last decade, however, there has been a dramatic increase in the number of authors publishing in JIBS from China, Canada, the Netherlands, Australia, Singapore and Germany.

An examination of the migration patterns of JIBS authors from 2008 to 2014 reveals that a little over half of all international business scholars are employed outside their country of birth. Of those who are employed in their country of birth, 
approximately $12 \%$ are return migrants, i.e. persons who left their country of birth to seek PhD education abroad and later returned. We find that there is a higher proportion of natives among authors whose PhDs were obtained outside the US, as compared to those whose PhD granting institution is in the US. Of the total number of PhD-seeking migrants, approximately one-third have US-PhDs; this suggests that scholars who pursue a PhD degree in the US tend to stay in the US and possibly help build new bridges of scholarship between their country of origin and country of residence. We also find that China has the highest number of returnees, followed by South Korea. This provides further evidence to the notion of brain circulation (Saxenian, 2005); return migrants also help bind their countries of origin into international knowledge networks, and JIBS is a vehicle for this.

\section{JIBS AUTHORSHIP LANDSCAPE}

To examine the composition of JIBS authorship, we began by collecting data containing detailed information on all articles published in JIBS from 1980 to 2014 from Thomson Reuters' Web of Science (WoS) database, which contains data from 1980 onwards. For the remaining years (i.e. 1970-1979), we collected the articles from JIBS archives. In addition to this, we downloaded electronic versions of all articles published in JIBS since 1970. This was done to collect author affiliation and $\mathrm{PhD}$ granting institution information from the biography included in the articles. For the cases where this information was missing, we used online sources to complete the dataset. We excluded the articles for 1970 and 1971 from our study, as these articles did not contain affiliation information.

As the WoS assigns editorials, review articles, book reviews etc. to the type "article", and that is not consistent with JIBS categories, we manually assigned each publication to categories used by JIBS. Thus research notes and perspectives were included as articles, while book reviews were excluded (see Table A4 in the Appendix for details). In all, our database included 1564 JIBS manuscripts from 2197 unique authors affiliated with institutions from 66 countries for our observation period. Authors' last and first name or initials defined unique authors. For each last name with multiple first names or initials, we checked uniqueness based on the initial of the first name and affiliation. Until 2007, the WoS data lists all author affiliations, it does not provide one-to-one correspondence between author and affiliation

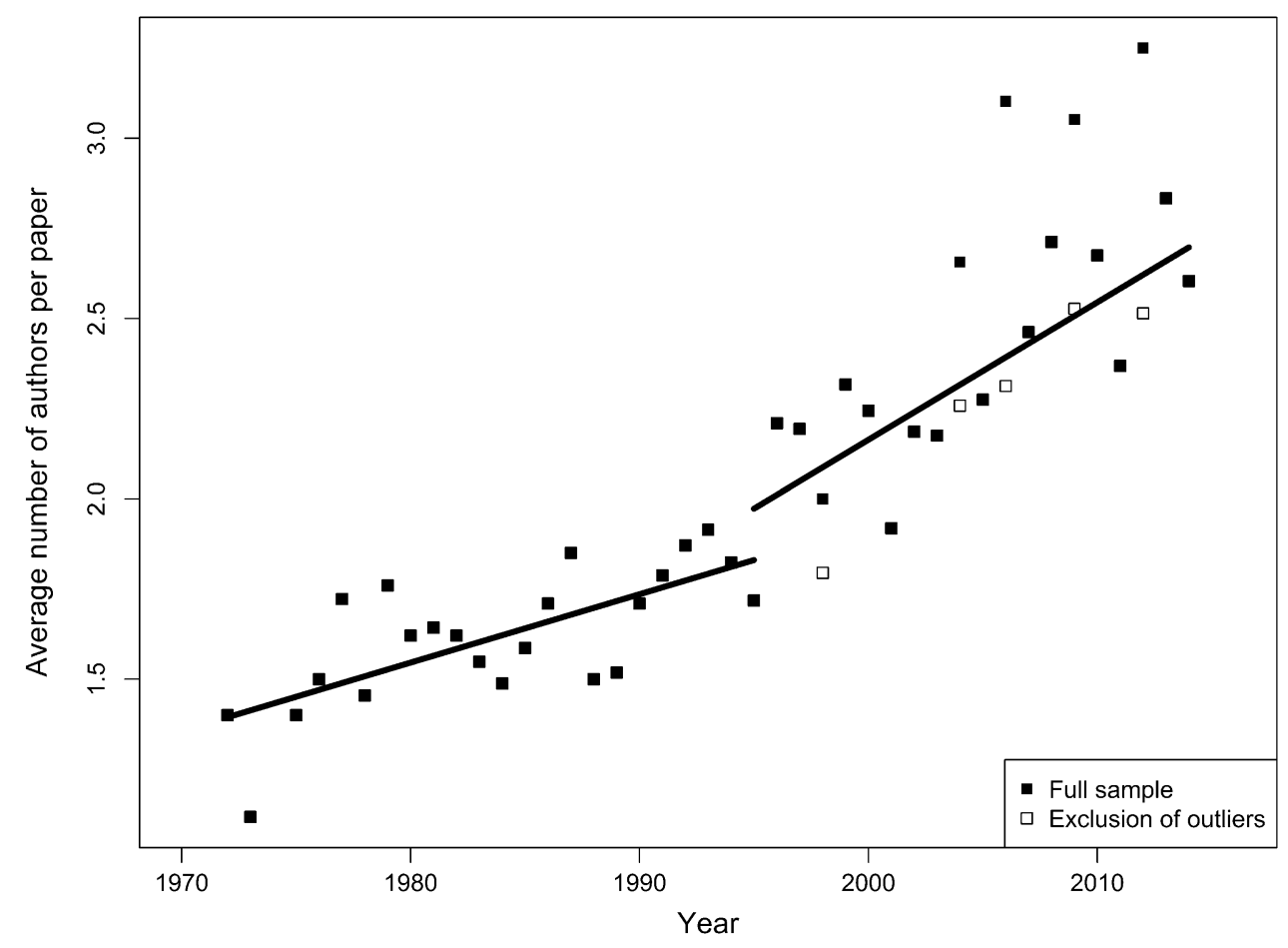

Figure 1 The average number of authors per JIBS article from 1972 to 2014. 
information; therefore, we manually mapped the affiliation information using the information provided in the corresponding journal article. We extracted the country of residence from the affiliation information of the authors. If an author was affiliated with institutions located in more than one country, we assigned all the countries to the author. Where the country information was missing, we manually assigned the country based on the identification of the institution. For 2008 onwards, the affiliation for each author and the country of residence information was extracted from WoS data. All calculations and analysis were performed using the statistical software R (R Core Development Team, 2015).

Preliminary data analysis revealed an overall increasing trend in the numbers of authors per paper for our observation period. Figure 1 shows the average number of authors per paper per year for articles published in JIBS from 1972 to 2014. The corresponding data for Figure 1 is provided in Table A5 in the Appendix. As shown in Figure 1, the trend line for the period from 1972 to 1995 has a slope of $0.0190(\mathrm{p}<0.001)$ while the period from 1995 to 2014 has a slope of $0.0402(p<0.001)$, which means that the speed of increase in the average number of authors of an article has doubled between the two time periods. This finding is consistent with other studies that also provide empirical evidence for increased knowledge production in teams. The solid squares in Figure 1 show the average values per paper when all papers are included, while the white squares show the average values per year without the outlier papers (five papers had more than nine authors, similarly four papers had more than nine countries of residence represented, based on author affiliations). Our chart is consistent with, for example, Wuchty, Jones, and Uzzi (2005), who examined 19.9 million papers over five decades and 2.1 million patents to show that solo authors or individual inventors are being gradually displaced by teams in the creation of new knowledge, where a team is defined as having multiple authors on a paper or research output. Adams, Black, Clemmons, and Stephan (2005) examined the trends in scientific teams in US research universities from 1981 to 1999 to find that team size increased by $50 \%$ over the observation period.

In sum, Figure 1 suggests that scholars are increasingly collaborating with others, and are part of research teams as opposed to being sole-authors on publications.

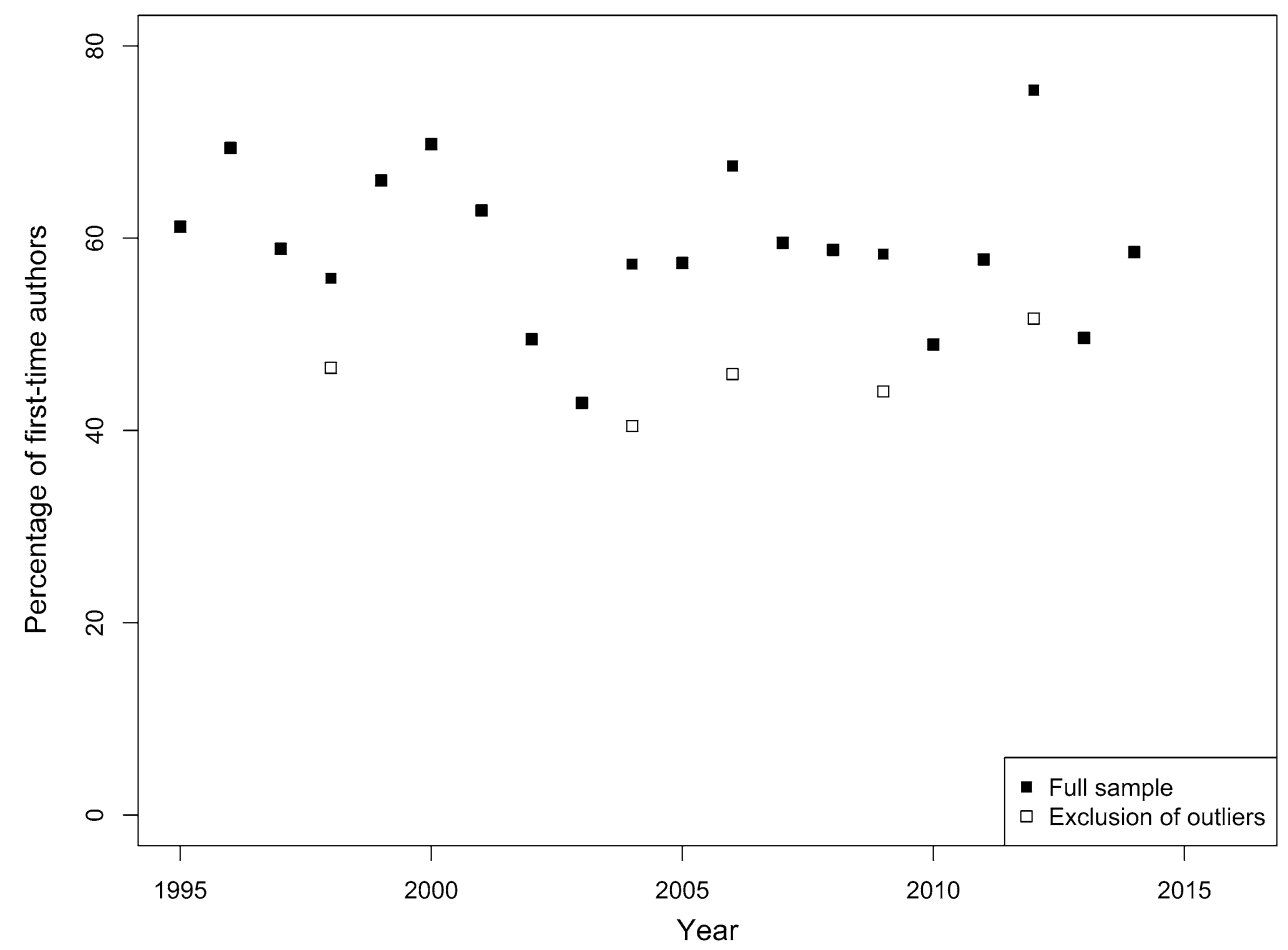

Figure 2 The percentage of first-time authors from 1995 to 2014. 

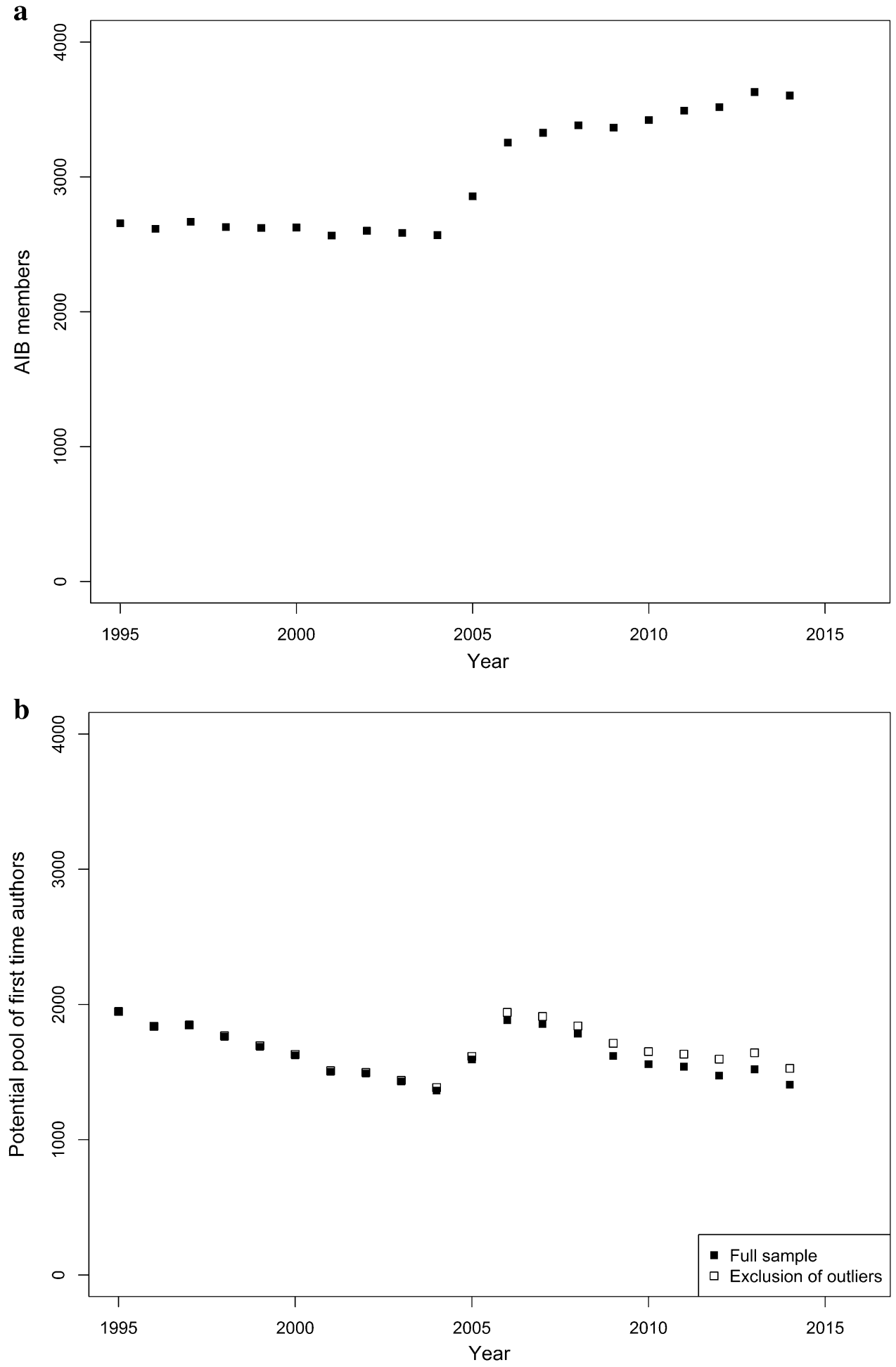

Figure 3 a AIB membership from 1995 to 2015. b Potential pool of first-time authors using AIB membership data. 


\section{ACCESSIBILITY OF JIBS}

\section{First-Time Authors}

To improve our understanding of the relative openness (or lack thereof) of the journal, we first examined the proportion of first-time authors publishing in JIBS. All authors who had published in the journal up until the end of 1994 were flagged as 'already published in JIBS.' Author data for 1995 onwards was then used to determine the percentage of first-time authorship. Figure 2 shows the percentage of firsttime authors for 1995-2014, whereby all authors who published before 1995 are counted in the inherited stock of existing authors. Figure 2 shows that on average about $60 \%$ of the authors publishing in JIBS are first-time authors (white squares represent the values when outliers were excluded). The data corresponding to Figure 2 is provided in Table A6 in the Appendix.

While not a perfect measure, we use the AIB membership count to represent the potential pool of authors who are likely to publish in JIBS. Figure 3a shows the number of AIB members from 1995 to 2015. Figure 3b shows the potential pool for first-time authors, which is the pool of all AIB members reduced by those members who have already published in JIBS. Figure $3 \mathrm{~b}$ shows that the prospective pool of first-time authors is shrinking as the number of new authors is on average higher than the increase in membership. The data for Figures $3 \mathrm{a}$ and $3 \mathrm{~b}$ is provided in Tables $\mathrm{A7a}$ and A7b in Appendix. For 2009-2014, we find that around $50 \%$ of first-time authors are AIB members (see Table A8 in the Appendix for details) at the time of the publication, and since there is no clear trend away from this proportion it suggests that changes in the AIB membership provide a reasonable proxy for changes in the overall pool of potential first time IIBS authors. Thus if the share of first time JIBS authors has remained roughly stable over time (Figure 2), while the approximate pool of potential first time authors in the existing IB scholarly community has been slowly shrinking (Figure 3b), this suggests that the journal is becoming gradually more open to first time authors breaking into the group of those that have published in JIBS.

\section{Repeat Authors}

To further assess the accessibility of JIBS, we examined how the share of repeat authors has varied over time. Since JIBS has been aiming to be open to new scholars, one might hope to observe a declining trend in the number of multiple repeat authors over time. For this purpose, we first coded the number of previous publications in JIBS for each author-year pair for all authors since 1980. Then, for each year, we calculated the percentage of authors who have at least three previous publications in JIBS. Figure 4 shows how the percentage of authors with at least three previous publications in JIBS has varied over time. Corresponding data for Figure 4 is shown in Table A9 in the Appendix. Clearly, there was a rise in the percentage of multiple repeat authors in the early years of the journal until about 2008. By using a polynomial fit to mimic the trend appropriately in Figure 4 , the fitted line had reached a plateau at around $15 \%$ of authors with three or more previous JIBS articles from 2005 to 2010 . However, the fitted line in Figure 4 shows a discernible declining trend in the percentage of multiple repeat authors from 2010 onwards. This trend suggests that in the term of the current editorial team since 2011, the journal has indeed become relatively more open to new scholars compared to already established JIBS authors. This is quite a convincing plotted change of direction, since the number of previously papers is naturally rising over time relative to the number of current articles, and so there has been a continued increase in the number of authors who have crossed the threshold of publishing three or more previous articles in JIBS.

As junior scholars can often write with established IB scholars, and quite commonly with their $\mathrm{PhD}$ advisor, we analyzed the data on previous publications for JIBS authors to be able to see how often first-time authors' co-authors are themselves repeat authors. For this purpose, we split the data on JIBS articles by the number of co-authors per publication: 235 articles with sole first-time authors were not included in this analysis. All other publications were grouped by the number of co-authors per publication. We identified 471 JIBS articles that were co-authored by two authors, at least one of whom was a first-time author. We then examined the number of publications for the other author(s) of these 471 articles. Table 1 shows the frequency distribution of the number of publications of a first-time authors' co-author. As shown in Table 1, 243 articles or nearly $50 \%$ of the articles in this category were comprised of author teams consisting of two authors, both of whom were publishing in JIBS for the first time. This suggests that while half of the first-time authors publishing in JIBS work with repeat-authors, the other half work with fellow first-time authors. 


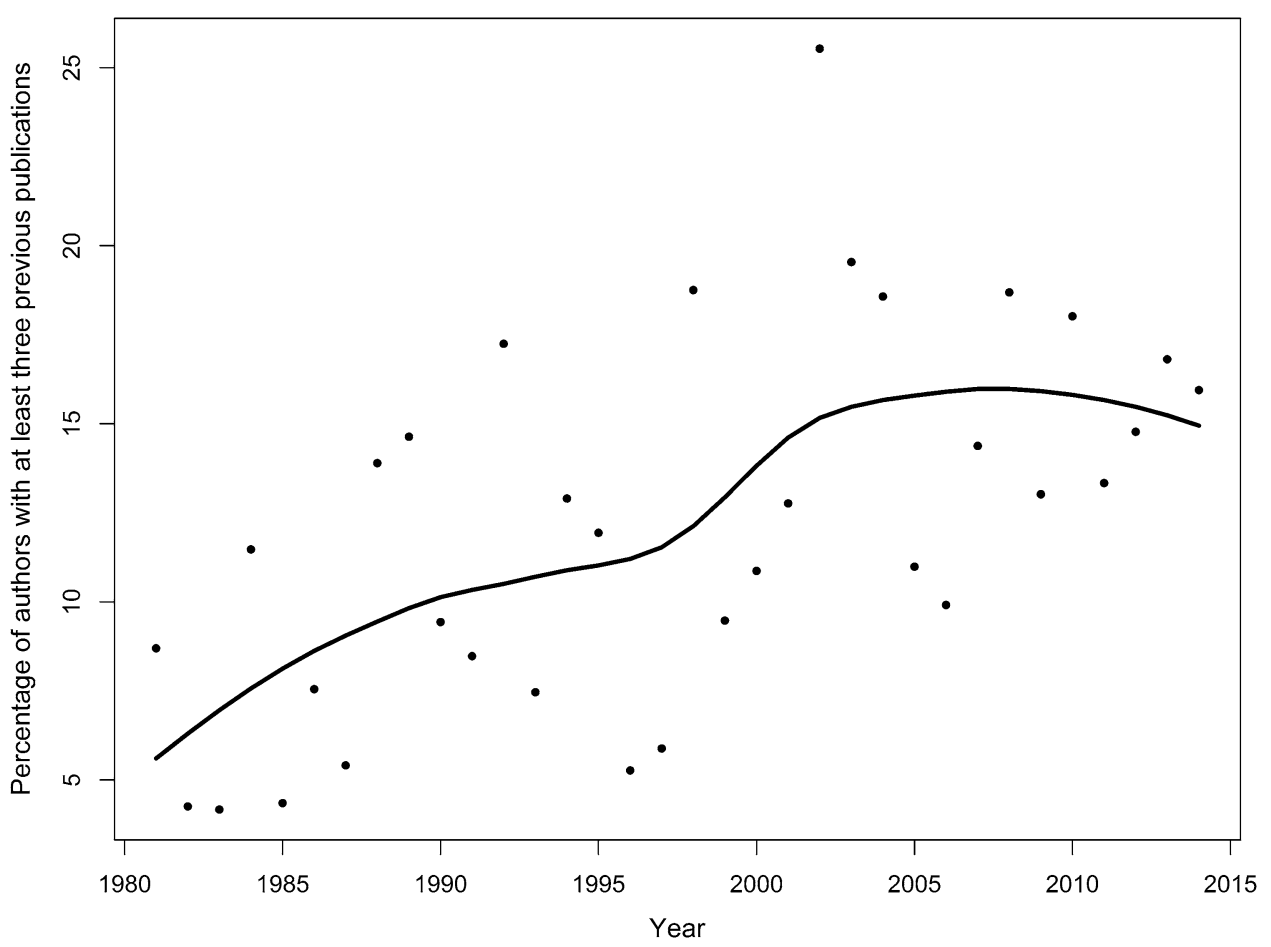

Figure 4 Percentage of authors with at least three previous publications in JIBS.

Table 1 Frequency distribution of previous publications of firsttime authors' co-author(s), 1980-2014

\begin{tabular}{lrr}
\hline $\begin{array}{l}\text { Number of previous } \\
\text { publications }\end{array}$ & Frequency & Percentage \\
\hline 0 & 243 & 51.59 \\
1 & 106 & 22.51 \\
2 & 47 & 9.98 \\
3 & 23 & 4.88 \\
4 & 17 & 3.61 \\
5 & 6 & 1.27 \\
6 & 7 & 1.49 \\
7 & 4 & 0.85 \\
8 & 3 & 0.64 \\
9 & 5 & 1.06 \\
10 & 3 & 0.64 \\
11 & 2 & 0.42 \\
12 & 2 & 0.42 \\
13 & 2 & 0.42 \\
14 & 1 & 0.21 \\
\hline
\end{tabular}

Similarly, we analyzed publications with three co-authors, when at least one author was a firsttime author. Of the 297 articles, 107 articles (36\%) had all three authors as first-time authors, and 114 (38\%) had two first-time authors. In other words, the majority of the papers with three authors had at least two first-time authors.

\section{DIVERSITY OF JIBS CONTRIBUTORS}

Collaboration often leads to more impactful research by bringing together the expertise and experience of different individuals on a research team. As countries have become increasingly specialized in technological knowledge, new knowledge creation requires sourcing of knowledge from locations around the world (Cantwell \& Vertova, 2004). This trend has been facilitated by the advent of the Internet and related telecommunication products that have made it easier to communicate and coordinate tasks across global teams. In the natural sciences, approximately $74 \%$ of the papers published are products of collaborative efforts of several institutions; in addition, over a third of the papers are internationally coauthored (The Royal Society, 2011). For S\&E journal articles more widely, the number of internationally coauthored articles has grown from $8 \%$ in 1988 to $16 \%$ in 1997, and then to $25 \%$ by 2012 (National Science Board, 2014). We find a similar trend increase for JIBS, but in the case of JIBS there is an even more impressive rise in the proportion of internationally coauthored articles, to around twothirds of the total. The number of internationally coauthored articles for JIBS has grown from $16.7 \%$ in 1988 to $32.3 \%$ in 1997 , and then to $66.7 \%$ in 2012. Figure 5 shows the average number of countries of 


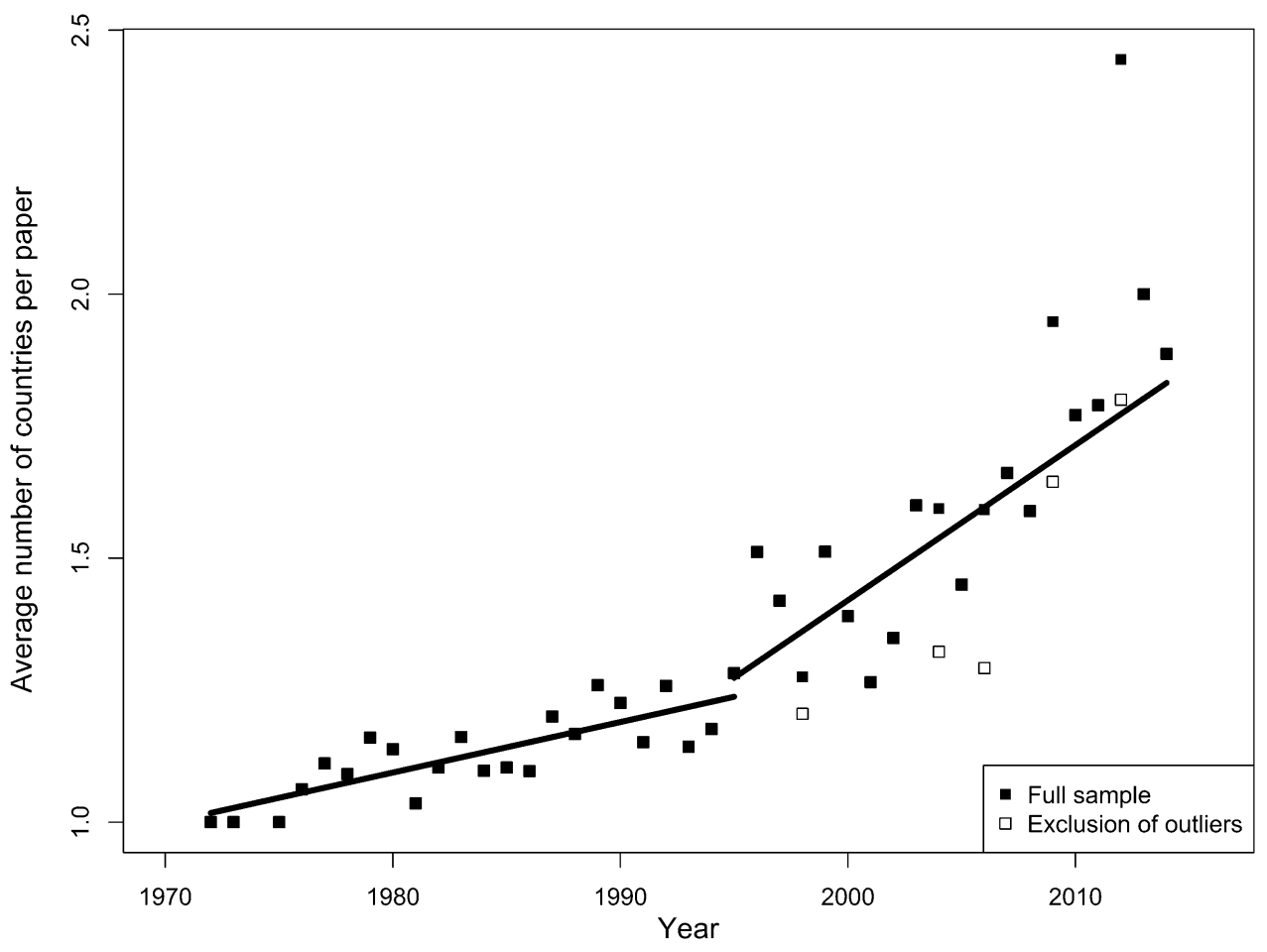

Figure 5 The average number of author countries of residence per JIBS article from 1972 to 2014.

residence of authors per paper per year for articles published in JIBS from 1972 to 2014 . We calculate the average number of countries represented per paper first, and then use these numbers to calculate the average for the entire year; these averages are provided in Table A10 in the Appendix. The solid squares in Figure 5 show the average values per paper when all papers are included, while the white squares show the average values per year without the outlier papers (five papers had more than nine authors, similarly four papers had more than nine countries of residence represented, based on author affiliations). The average number of countries of residence represented (indicated by author affiliations), per paper showed an overall rising trend.

The two lines in Figure 5 show the slope based on simple regression estimations for the two periods. The slope is $0.0096(\mathrm{p}<0.001)$ for the first period (i.e. 1972-1995) and it is $0.0304(p<0.001)$ for the second period (i.e. 1995-2014). While the slope in the second period doubled for the average number of authors, it triples for the average number of countries of residence of these authors. This demonstrates that an increasing internationalization of research collaborations has occurred above and beyond the increasing number of authors per research collaboration. Furthermore, the average number of countries per paper is approaching the level of two, which suggests that internationally coauthored articles have become the norm. This is corroborated by the median of two countries of residence per paper since 2010 .

\section{Geographic Spread of Authors}

To examine the geographic spread of JIBS authorship, we relied on the country of the university with which an author was affiliated. Figure 6 shows the percentage distribution of authors from North America, Europe, Asia-Pacific and the remaining countries (shown as 'Other'). The data corresponding to Figure 6 is provided in Table A11 in the Appendix. As shown in Figure 6, the percentage of authors from North America has declined considerably since the journal began in 1970. A rising share of authors from the Asia-Pacific region and the European region has accompanied this declining trend in authors affiliated with North American institutions. As the growth in the number of business schools (and thus the expectation to publish in major journals), in several countries around the globe, may be contributing to the increased geographic dispersion of the JIBS authorship landscape, we looked at the regional distribution of business schools for comparison purposes. A 


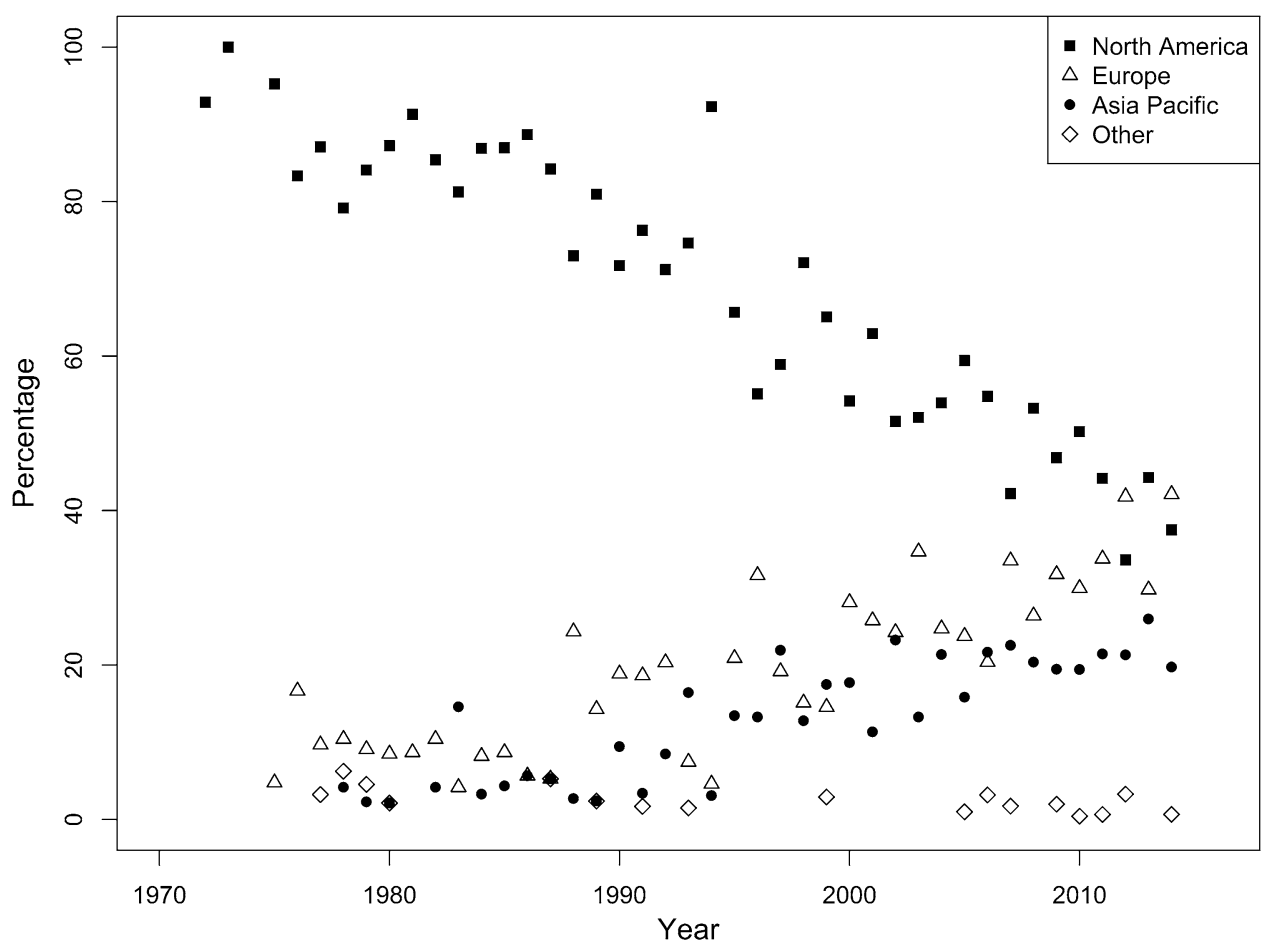

Figure 6 Percentage distributions of authors from North America, Europe, Asia-Pacific and Other.

Table 2 Top twenty countries by frequency of author affiliations for 1995-2004 and 2005-2014

\begin{tabular}{|c|c|c|c|c|c|}
\hline \multicolumn{3}{|l|}{ 1995-2004 } & \multicolumn{3}{|c|}{ 2005-2014 } \\
\hline Country & Authors & $\%$ distribution & Country & Authors & $\%$ distribution \\
\hline USA & 480 & 55.24 & USA & 656 & 41.84 \\
\hline UK & 96 & 11.05 & China & 152 & 9.69 \\
\hline China & 77 & 8.86 & Canada & 139 & 8.86 \\
\hline Canada & 53 & 6.10 & UK & 136 & 8.67 \\
\hline Netherlands & 25 & 2.88 & Netherlands & 90 & 5.74 \\
\hline France & 24 & 2.76 & Australia & 68 & 4.34 \\
\hline Sweden & 17 & 1.96 & Singapore & 38 & 2.42 \\
\hline Australia & 14 & 1.61 & Germany & 37 & 2.36 \\
\hline Denmark & 12 & 1.38 & Sweden & 34 & 2.17 \\
\hline South Korea & 12 & 1.38 & France & 31 & 1.98 \\
\hline Singapore & 11 & 1.27 & Finland & 28 & 1.79 \\
\hline Taiwan & 10 & 1.15 & Denmark & 26 & 1.66 \\
\hline Finland & 6 & 0.69 & Belgium & 25 & 1.59 \\
\hline Norway & 6 & 0.69 & Spain & 25 & 1.59 \\
\hline Spain & 5 & 0.58 & South Korea & 20 & 1.28 \\
\hline Israel & 5 & 0.58 & Italy & 17 & 1.08 \\
\hline Japan & 5 & 0.58 & Taiwan & 13 & 0.83 \\
\hline Germany & 4 & 0.46 & Israel & 12 & 0.77 \\
\hline Belgium & 4 & 0.46 & Japan & 11 & 0.70 \\
\hline Italy & 3 & 0.35 & Norway & 10 & 0.64 \\
\hline Total & 869 & $100 \%$ & Total & 1568 & $100 \%$ \\
\hline
\end{tabular}

comparison of the geographic distribution of the authors of JIBS articles (as shown in Table A11 in the Appendix) with the equivalent shares of the top
100 business schools by region (see Table A12 for details for corresponding years) shows that the former is higher for Europe and Asia, but it has 


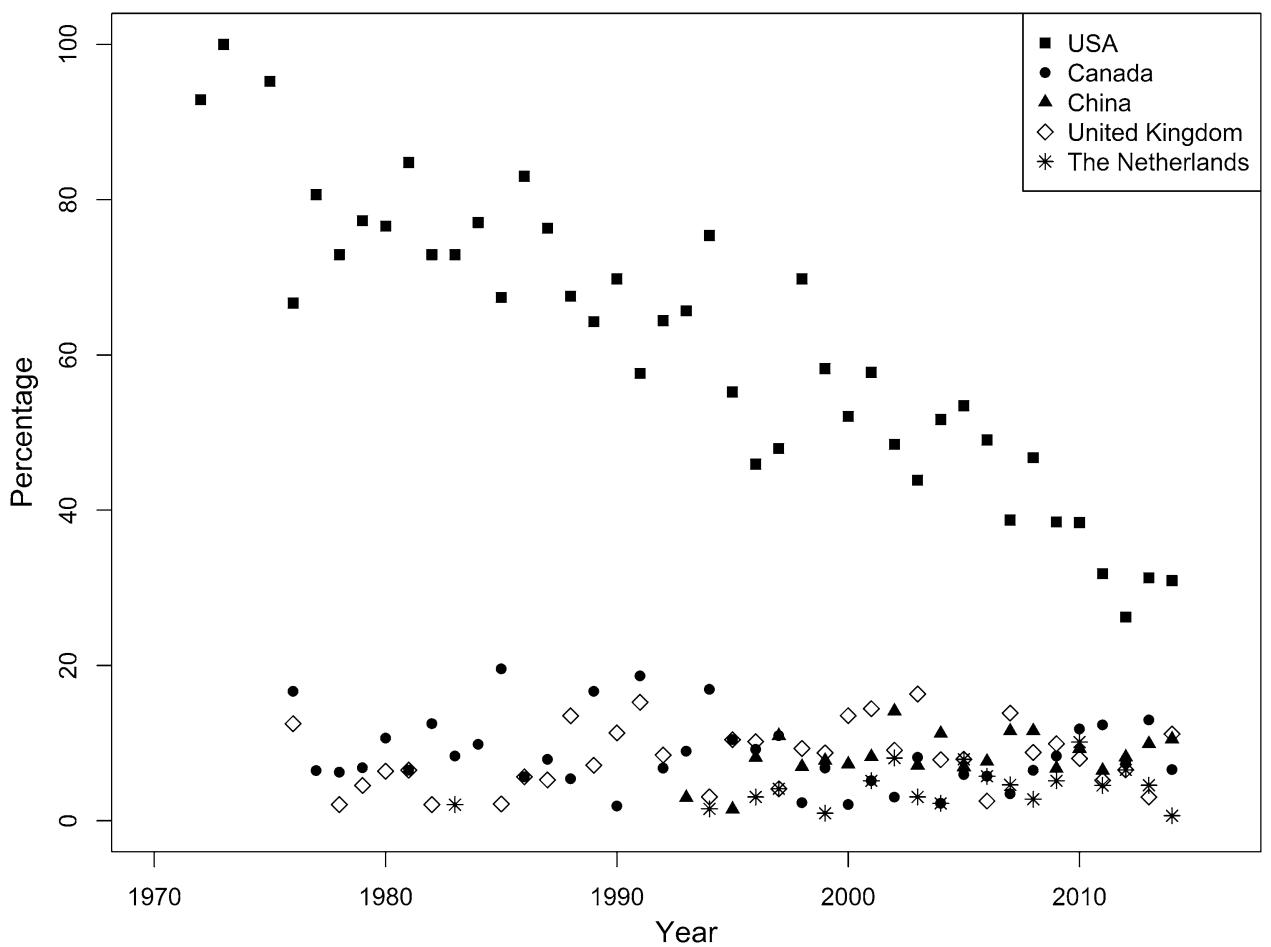

Figure 7 Percentage distributions of authors from the USA, Canada, China, the UK and the Netherlands.

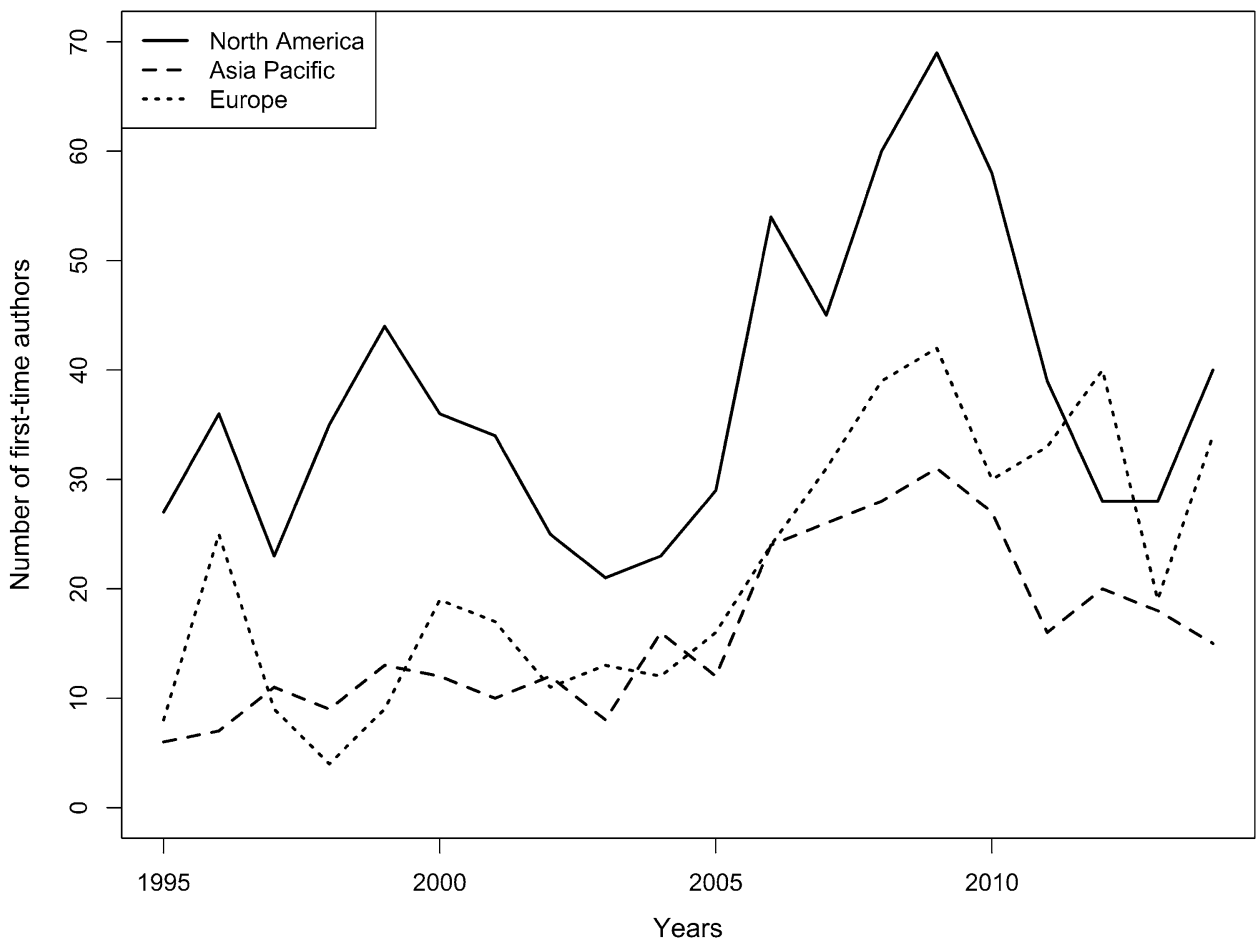

Figure 8 Regional distribution of first-time authors. 
Table 3 Categories of JIBS authors based on mobility patterns

\begin{tabular}{llll}
\hline $\begin{array}{l}\text { Category } \\
\text { name }\end{array}$ & $\begin{array}{l}\text { Country } \\
\text { of origin } \\
\text { (or birth) }\end{array}$ & $\begin{array}{c}\text { Country of } \\
\text { PhD-granting } \\
\text { institution }\end{array}$ & $\begin{array}{c}\text { Country } \\
\text { of university } \\
\text { affiliation }\end{array}$ \\
\hline Natives & $\checkmark$ & $\checkmark$ & $\checkmark$ \\
PhD-seeking migrants & $\mathrm{X}$ & $\checkmark$ & $\checkmark$ \\
Nomads & $\mathrm{X}$ & $\mathrm{X}$ & $\mathrm{X}$ \\
Returnees & $\checkmark$ & $\mathrm{X}$ & $\checkmark$ \\
Job-seeking migrants & $\boldsymbol{V}$ & $\boldsymbol{X}$ & $\mathrm{X}$ \\
\hline
\end{tabular}

Table 4 Mobility categories of JIBS authors using 2008-2014 data

\begin{tabular}{lrcrr}
\hline Mobility & \multicolumn{3}{c}{ Author roles } & \begin{tabular}{c} 
Percentage \\
of JIBS \\
\cline { 2 - 4 }
\end{tabular} \\
\cline { 2 - 4 } Total & $\begin{array}{c}\text { Non-US } \\
\text { PhDs }\end{array}$ & $\begin{array}{c}\text { US- } \\
\text { PhDs }\end{array}$ & \\
\hline Nathors & 303 & 173 & 130 & 39 \\
PhD-seeking migrant & 219 & 63 & 156 & 28 \\
Job-seeking migrant & 56 & 46 & 10 & 7 \\
Returnee & 98 & 46 & 52 & 12 \\
Nomad & 110 & 56 & 54 & 14 \\
Total & 786 & 384 & 402 & 100 \\
\hline
\end{tabular}

fallen lower for North America. This suggests that the rise in the number of JIBS authors affiliated with universities in Europe and Asia-Pacific is more than the rise in the number of business schools in the respective regions.

Following Thomas et al. (1994), we examine the frequency distribution of author affiliations by country in order to investigate which countries have emerged on the authorship landscape of JIBS since 1995. Table 2 shows the top twenty countries ranked by the number of author affiliations by country for JIBS articles published during the last twenty years (1995-2004 and 2005-2014). A comparison of the list of countries for the 1995-2004 period as shown in Table 2, with the frequency of author affiliations by country for the 1970-1993 period from Table 2 of Thomas et al. (1994) reveals that authors from China, Denmark and Finland entered the author landscape of JIBS during the 1995-2004 period. The increase in the number of JIBS authors affiliated with Chinese universities is especially noteworthy. While no authors affiliated with universities in China appeared on the landscape of JIBS authors for the 1970-1993 period (Thomas et al., 1994: 681), our results show that they are the third largest contributor for the 1995-2004 period. For the 2005-2014 period China moved up further to become the second largest country of residence of JIBS authors. While the USA continues to have the largest number of authors in absolute terms in both time periods as shown in Table 2, other countries such as China, Canada, the Netherlands, Australia, Singapore and Germany have seen a multifold increase in the last ten years in comparison to the 1995-2004 period. Table 2 shows that on average, authors from five countries - namely the USA, China, Canada, the UK and the Netherlands - have dominated the JIBS landscape for the 2005-2014 period. Figure 7 shows how contributors from these five countries have varied over time.

To improve our understanding of the regional distribution of first-time authors, we plotted the shares of first-time authors from the North American, Asian Pacific and European regions, the counterpart of Figure 6 for this subset of authors. Figure 8 shows the regional distribution of firsttime authors for these geographic regions. ${ }^{1}$ The corresponding data for this figure is provided in Table A13 in the Appendix. When compared to Figure 6, this shows how the influx of first time JIBS authors has for some time been relatively more equally dispersed across the major international regions, relative to the established JIBS author base. This comparatively even international spread of first time JIBS authors between North America, Europe and Asia has been accentuated since 2011.

\section{Mobility}

The increase in the geographic spread of research collaborations can be attributed partly to the increased migration of scholars and scientists across borders. For example, Scellato, Franzoni, and Stephan (2014) find that foreign-born scientists as well as return scientists tend to have co-authorship networks that are larger than those of native researchers without international background. Return scientists catalyze production of knowledge in their country of origin (Choudhury, 2015; Wang, 2015), and this knowledge is often of higher quality (Perri, Giada Scalera, \& Mudambi, 2015). Foreign-born scientists help build new bridges of scholarship between their countries of origin and residence. More than a third of foreign-born scientists have research partnerships with their counterparts in their countries of origin (Scellato et al., 2014). Cross-border partnerships have become more functional and practical in the last few decades, in part due to advances in information, communication and transportation technologies. 
Table 5 Geographic distribution of JIBS contributors in five categories by the country of their PhD

\begin{tabular}{|c|c|c|c|c|c|}
\hline & Job-seeking migrants & PhD-seeking Migrants & Natives & Nomads & Returnees \\
\hline Australia & 1 & 10 & 11 & 3 & 1 \\
\hline Austria & 3 & 0 & 3 & 0 & 0 \\
\hline Belgium & 2 & 1 & 5 & 1 & 2 \\
\hline Brazil & 0 & 0 & 1 & 0 & 0 \\
\hline Bulgaria & 0 & 0 & 0 & 0 & 0 \\
\hline Canada & 2 & 16 & 15 & 19 & 14 \\
\hline China & 4 & 0 & 17 & 0 & 0 \\
\hline Croatia & 0 & 0 & 1 & 0 & 0 \\
\hline Denmark & 1 & 2 & 7 & 2 & 0 \\
\hline Finland & 4 & 1 & 13 & 0 & 0 \\
\hline France & 1 & 0 & 1 & 2 & 3 \\
\hline Germany & 5 & 1 & 21 & 1 & 1 \\
\hline Greece & 1 & 0 & 0 & 0 & 0 \\
\hline India & 1 & 0 & 2 & 0 & 0 \\
\hline Ireland & 0 & 2 & 1 & 0 & 1 \\
\hline Israel & 0 & 0 & 3 & 0 & 0 \\
\hline Italy & 3 & 0 & 3 & 0 & 0 \\
\hline Japan & 0 & 0 & 1 & 0 & 0 \\
\hline Lithuania & 0 & 0 & 1 & 0 & 0 \\
\hline Mexico & 0 & 0 & 1 & 0 & 0 \\
\hline Netherlands & 3 & 2 & 17 & 2 & 1 \\
\hline New Zealand & 0 & 0 & 1 & 1 & 2 \\
\hline Norway & 0 & 2 & 3 & 0 & 0 \\
\hline Portugal & 1 & 0 & 3 & 1 & 0 \\
\hline Russia & 2 & 0 & 0 & 0 & 0 \\
\hline Singapore & 0 & 0 & 1 & 1 & 2 \\
\hline Slovenia & 1 & 0 & 3 & 0 & 0 \\
\hline South Korea & 0 & 0 & 3 & 0 & 0 \\
\hline Spain & 1 & 1 & 5 & 2 & 2 \\
\hline Sri Lanka & 1 & 0 & 0 & 0 & 0 \\
\hline Sweden & 3 & 1 & 9 & 1 & 0 \\
\hline Switzerland & 2 & 1 & 0 & 1 & 0 \\
\hline Turkey & 1 & 0 & 0 & 0 & 0 \\
\hline UK & 3 & 23 & 21 & 18 & 17 \\
\hline Ukraine & 0 & 0 & 0 & 0 & 0 \\
\hline USA & 10 & 156 & 130 & 54 & 52 \\
\hline
\end{tabular}

While "broadband penetration had a significant impact" (Choi, 2012: 39) on the co-authorship networks in research collaborations, it is not a defining factor (Choi, 2012). In today's highly connected world, face-to-face contact is necessary (as opposed to online contact only) for the initiation of collaboration ties (Choi, 2012). The foundation for collaboration ties are more likely to be laid through face-to-face contact of a scholar with other scholars in an organizational setting. These include but are not limited to universities, educational institutions, professional associations, and research labs to name a few. One would expect, therefore, that the greater is the cross-border geographical dispersion of institutions attended by scholars, the greater is the likelihood of increased participation in international collaborations. For this investigation, we used the biographical details of authors who have published in JIBS from 2008 to 2014 . $^{2}$ We relied primarily on the country of birth, country of the PhD-granting institution, and the country of the university affiliation (associated with the publication) for categorizing JIBS authors into the following five groups - (1) Natives, (2) PhD-seeking migrants, (3) Job-seeking migrants, (4) Returnees and (5) Nomads.

Scholars whose country of birth, country of PhDgranting institution and country of university affiliation (associated with the publication) are the same, we term natives. Scholars whose country of birth is different from their common country of PhD-granting institution and their country of affiliation, we term PhD-seeking migrants. Scholars 


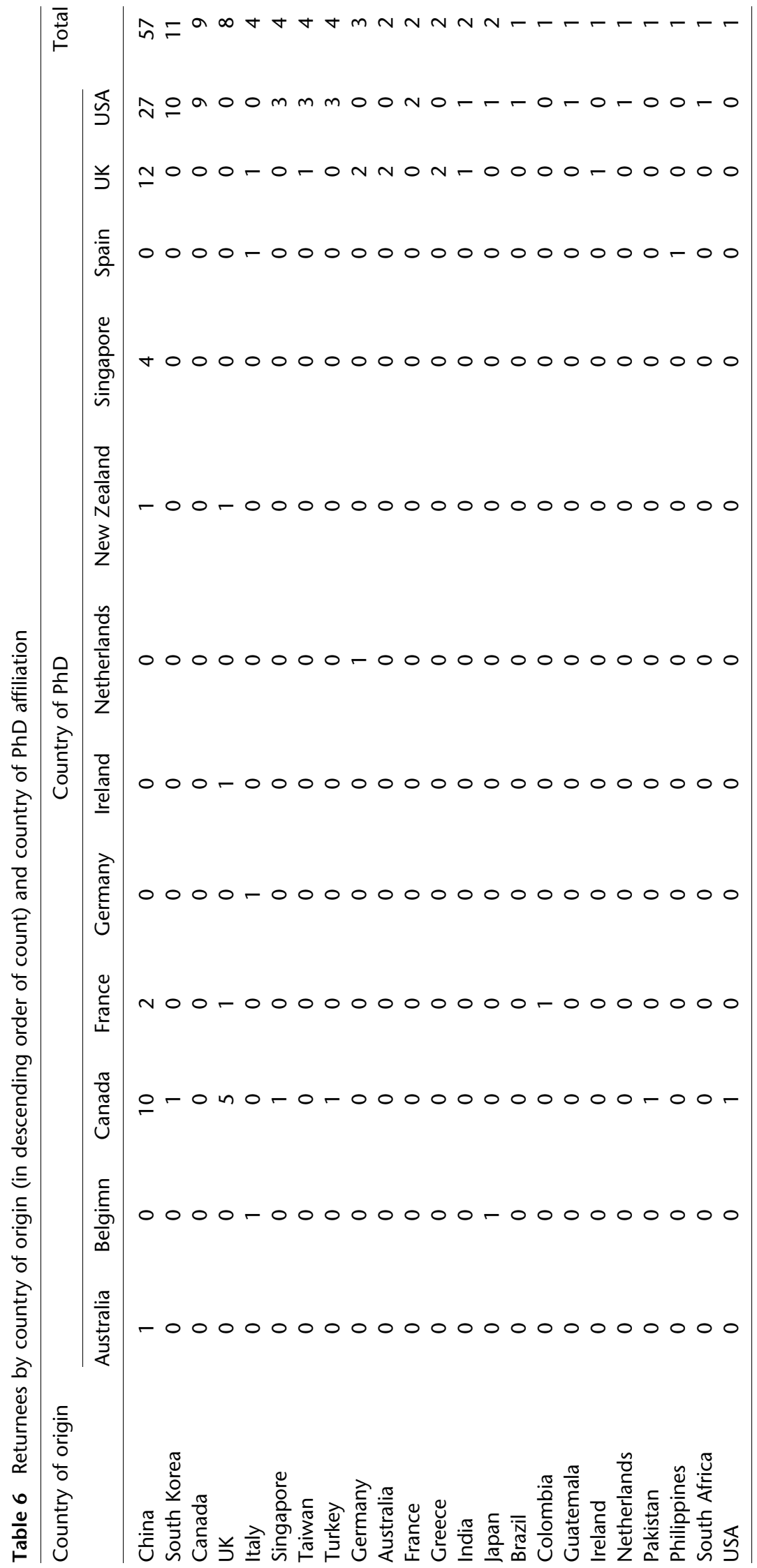




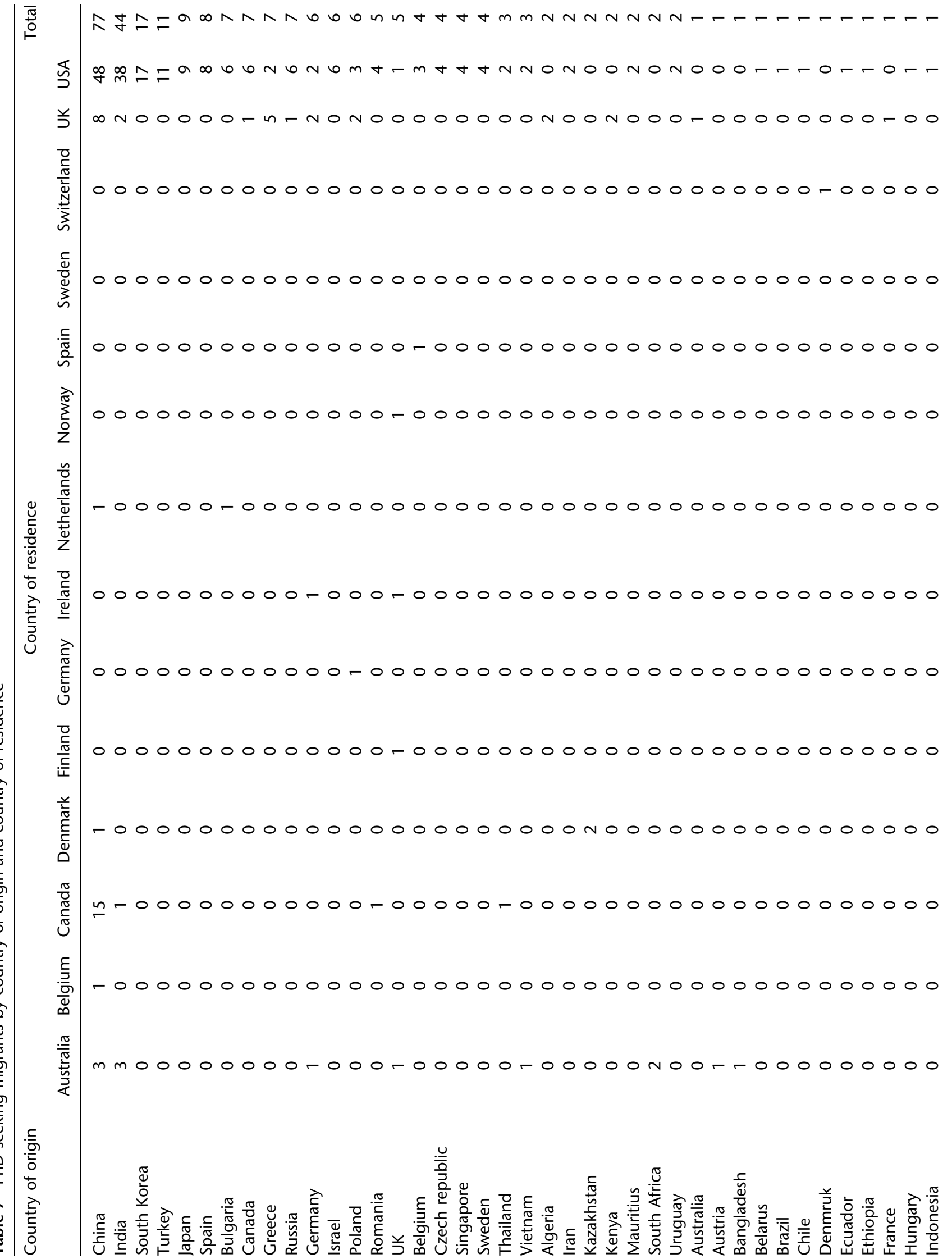




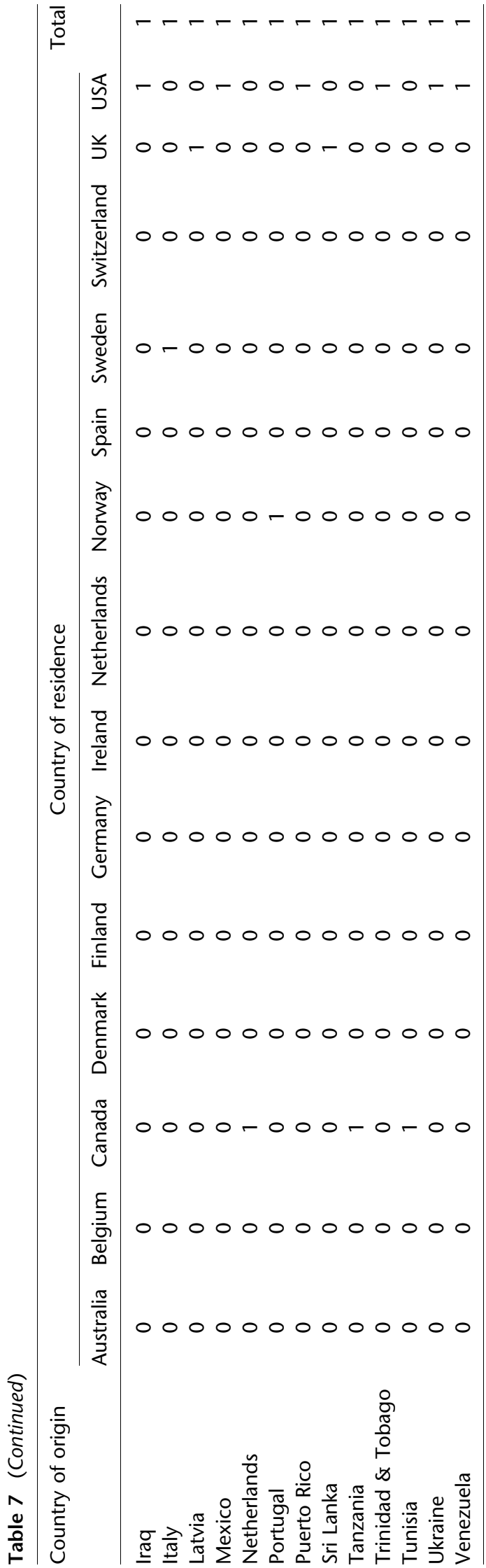

whose country of PhD-granting institution and country of affiliation are different, we name jobseeking migrants. Scholars with the same country of birth and affiliation, but a different country of PhDgranting institution are referred to as returnees, a term frequently used in the migration literature. And lastly, scholars whose country of birth, country of PhD-granting institution, and country of affiliation are all different, we describe as nomads. To illustrate this with an example, if a JIBS author born in India completed her PhD education in India and was employed at a university in India, we assigned her to the native category. As another illustration with regard to more than one assignment (aka dual role), if an author, who had published in JIBS, while being a native, moves to another country and has yet another publication in JIBS, then he or she will be in our database twice - once as native, and once as a job-seeking migrant. Table 3 shows the categories of JIBS authors based on their mobility patterns; a check mark $(\boldsymbol{V})$ represents common countries, whereas a cross (X) indicates a country that is different from the others for that category.

Our initial data set consisted of 915 authors, who had published in JIBS from 2008 to 2014 . For mobility analysis, we focused only on those authors who were affiliated with a unique university at a given point in time. For this purpose, we 31 excluded authors with multiple affiliations; this reduced our sample to 884 authors. Of these 884 authors, we discarded additional 104 authors. While many of these 104 authors were missing biographical information, some of these authors were students and so they did not have a work university affiliation. Thus our final sample consisted of 780 authors. As six authors had dual roles during our observation period, Table 4 shows 786 roles for the 780 authors. As noted earlier, dual roles occur when for example, natives go abroad later in their career, or job-seeking migrants move to another country thereby becoming a nomad by our definition, or if a scholar returns to her home country after being a nomad. As there is a (somewhat close to) oneto-one correspondence between individual authors and author roles (only six authors have dual roles), we calculate the percentage of authors that belong to each category in order to shed further light on the mobility patterns of IB scholars. Table 4 shows that, of the authors who have published in JIBS since 2008, about $39 \%$ were natives; $28 \%$ were PhD-seeking migrants, or in other words their country of origin and country of $\mathrm{PhD}$ granting institution are different; and $14 \%$ were nomads, meaning that their country of origin, country of PhD granting institution and 
country of (work) university institution affiliation were all different. Returnees constituted about $12 \%$ of all authors in our observation period and jobseeking migrants constituted the lowest share approximately $7 \%$ of our sample.

Table 4 also shows that academic mobility has reinforced the trend towards the greater internationalization of the population of JIBS authors, away from natives born, educated and employed in the US. About two-fifths of $J I B S$ authors with US PhDs were PhDseeking migrants, and most $\mathrm{PhD}$-seeking migrants found their opportunity in the US. Meanwhile, over four-fifths of job-seeking migrants had non-US PhDs, authors who found their employment opportunity in another country (which was sometimes in the US) after completing their $\mathrm{PhD}$.

Furthermore, these JIBS author mobility patterns are not merely reducible to foreign scholars seeking better opportunities in the US. While scholars seeking $\mathrm{PhDs}$ in the US are greater in number (402), those who sought PhDs in other countries (primarily European countries) are nearly as high in number (384). According to Table 4, non-US PhDs had a higher number of natives (173) who chose to stay in their country of origin as compared to US PhDs (130). Table 5 shows the distribution of JIBS authors in the five categories organized by country of PhD-granting institution. Table 5 allows us to see in greater detail the geographic distribution of authors in our sample. While most PhD-seeking migrants were in the US, other quite popular choices were the UK, Canada and Australia. With regard to natives, the USA has the highest number as noted earlier, but scholars in several other countries also tend to stay in their country of origin; these include Germany (21), the UK (21), Netherlands (17) and China (17).

Next, we organized these data by country of origin of authors to see which countries receive the highest number of returnees. Table 6 shows the returnees by country of origin and country of PhD affiliation of authors. We find that China has the highest number of returnees (57) in our sample. This may partly explain the increase in the number of authors affiliated with Chinese universities on the JIBS landscape in the 2005-2014 period. Other countries with a high number of returnees include South Korea (11), Canada (9) and the UK (8).

We also organized these data for PhD-seeking migrants, as shown in Table 7; the rows represent the country of origin of scholars, while the columns represent both, the country of PhD-granting institution as well as their place of work. Scholars from China (77), India (44), South Korea (17), Turkey (11) and Japan (9) rank the highest in this category. In other words, scholars from these countries of origin are most likely to take up a job in their country of PhDgranting institution. A comparison of returnees and PhD-seeking migrants by their country of origin (as shown in Table 6 and 7 respectively) depicts some interesting migration patterns. For instance, India has only 2 returnees, but $44 \mathrm{PhD}$-seeking migrants, suggesting more out-migration from India, as opposed to return migration. For those $44 \mathrm{PhD}$ seeking migrants from India, the main destinations are USA (38), Australia (3), UK (2) and Canada (1), as shown in Table 7 . China, on the other hand, has 77 PhD-seeking migrants, but also has a higher number of returnees (57). The main destinations for PhDseeking migrants from China are the USA (48), Canada (15), the UK (8) and Australia (3).

Lastly, we organized these data for job-seeking migrants (see Table A14 in the Appendix for details) and for nomads (see Table A15 in the Appendix for details). The USA (10), Canada (5), China (5), Finland (5), Germany (5) and Russia (5) rank the highest in job-seeking category of scholars. In other words, scholars from these countries complete their PhD in their country of origin and then take up a position in a foreign country. These numbers are relatively smaller than the numbers for both returnees and PhD-seeking migrants. Finally, in the nomad category of scholars, we find that China (21), India (21), South Korea (13), France (11) and Germany (11) rank the highest, as shown in Table A15 in the Appendix.

As mobile inventors tend to be more productive than non-movers (Hoisl, 2007), we investigated whether a similar relationship exists for IB scholars as well. For this purpose, we calculated the average citation score for each of the five categories mentioned above. The scores for each of the five categories are as follows - Native 15.99, PhD-seeking migrant 17.3, Job-seeking migrant 16.87, Returnee 17.11 and Nomad 12.58. The pairwise $t$ test indicates, however, that there are no significant differences between these five categories. This could be related to the fact that an article often has a mix of author roles and contributions, so we may not be capturing the true productivity of an individual author.

\section{CONCLUSIONS}

Consistent with the editorial policy of JIBS, the journal is now more open and accessible than at any time in its history. To assess the accessibility of JIBS and the diversity of JIBS contributors, we collected and mapped IIBS author data from the 
early years of the journal to 2014. Our analysis revealed that JIBS is indeed becoming more open, as indicated by the rising proportion of first-time contributors to the journal compared to already well established JIBS authors. We have found that approximately $60 \%$ of the authors contributing to JIBS are those who have never published in JIBS before. In addition to that, we have found that the percentage of repeat authors, specifically those with three or more publications in JIBS, has been for the first time on a discernible downward trend since 2010.

Consistent with the findings of studies that have observed an increase in international co-authorship since the 1990s in the S\&E disciplines, we have also found that international research collaborations are on the rise for JIBS. Since increased mobility of scientists facilitates increased international research collaborations (Choi, 2012; Luukkonen, Persson, \& Sivertsen, 1992; Scellato et al., 2014), we also investigated the mobility patterns of JIBS authors. Our analysis of these patterns of authors, who have published in JIBS from 2008 to 2014, suggests that a little over half $(51 \%)$ of all international business scholars are employed outside their country of birth. Of those who are employed in their country of birth (49\%), $12 \%$ were return migrants.

\section{LIMITATIONS}

While the original intent was to include the data for all years since the journal came into existence in 1970, we had to exclude 1970 and 1971 from our analysis, because authors' affiliation information was not included in the journal articles at that time. However, this led to a rather small distortion in the pool of incumbent authors. With regard to mobility

\section{REFERENCES}

Adams, J. D., Black, G. C., Clemmons, J. R., \& Stephan, P. E. 2005. Scientific teams and institutional collaborations: Evidence from US universities, 1981-1999. Research Policy, 34(3): 259-285.

Cantwell, J., \& Vertova, G. 2004. Historical evolution of technological diversification. Research Policy, 33: 511-529.

Choi, S. 2012. Core-periphery, new clusters, or rising stars? International scientific collaboration among 'advanced' countries in the era of globalization. Scientometrics, 90(1): 25-41.

Choudhury, P. 2015. Return migration and geography of innovation in MNEs: A natural experiment of knowledge production by local workers reporting to return migrants. Journal of Economic Geography, 16: 3585-3610.

Edler, J., Fier, H., \& Grimpe, C. 2011. International scientist mobility and the locus of knowledge and technology transfer. Research Policy, 40(6): 791-805.

Hoisl, K. 2007. Tracing mobile inventors-The causality between inventor mobility and inventor productivity. Research Policy, 36: 619-636. analysis, we were restricted to data from 2008 onwards, as JIBS only recently began collecting biographical information of authors. As a result, we have been unable to discern trends over time in our migrant categories of JIBS authors. Furthermore, we had to discard approximately $10 \%$ of the observations as important biographical information was missing for these authors. Lastly, we excluded 31 authors with multiple affiliations to avoid a mix of mobility roles for individuals. However, it must be noted that these represented a very small percentage of the observations in our sample.

\section{ACKNOWLEDGMENTS}

We thank six JIBS area editors for their invaluable comments that have helped us in improving this piece. We thank Anne Hoekman, managing editor of JIBS, for providing biographical information of authors who have published in JIBS since 2008. We thank Tunga Kiyak, managing director of the AIB, for providing AIB membership data for this editorial. We also thank research assistants Nigar Asgarova and Sevinj Huseynova for downloading and extracting author information from pdfs for the early years of the journal. All errors are ours.

\section{NOTES}

${ }^{1}$ We excluded 'Other' regions from this graph for clarity; however the graph with all four regions is available to interested readers upon request.

${ }^{2}$ JIBS began collecting these data from 2008 onwards; therefore our mobility analysis is restricted to this time period.

Luukkonen, T., Persson, O., \& Sivertsen, G. 1992. Understanding patterns of international scientific collaboration. Science, Technology and Human Values, 17(1): 101-126.

National Science Board. 2014. Science and Engineering Indicators 2014. Arlington, VA: National Science Foundation (NSB 14-01).

Perri, A., Giada Scalera, V., \& Mudambi, R. 2015. An analysis of the co-inventor networks associated with the Chinese pharmaceutical industry. Paper presented at DRUID15, June 15-17, 2015, LUISS, Rome.

R Core Development Team. 2015. R: A language and environment for statistical computing. Vienna: $\mathrm{R}$ Foundation for Statistical Computing.

Saxenian, A. L. 2005. From brain drain to brain circulation: Transnational communities and regional upgrading in India and China. Studies in Comparative International Development, 40(2): 35-61. 
Scellato, G., Franzoni, C., \& Stephan, P. 2014. Migrant scientists and international networks. Research Policy, 44: 108-120.

The Royal Society. 2011. Knowledge, networks and nations: Global scientific collaboration in the 21 st century. London: The Royal Society.

Thomas, A. S., Shenkar, O., \& Clarke, L. 1994. The globalization of our mental maps-Evaluating the geographic scope of JIBS coverage. Journal of International Business Studies, 25(4): 675-686.
Wang, D. 2015. Activating cross-border brokerage: Interorganizational knowledge transfer through skilled return migration. Administrative Science Quarterly, 60(1): 133-176.

Wuchty, S., Jones, B. F., \& Uzzi, B. 2007. The increasing dominance of teams in production of knowledge. Science, 316(5827): 1036-1039.

\section{APPENDIX}

See Tables A1, A2, A3, A4, A5, A6, A7a, A7b, A8, A9, A10, A11, A12, A13, A14, A15 and Figures A1 and A2.

Table A1 The new membership counts for various years for the Academy of International Business, since 1980

New AIB members by year

\begin{tabular}{lr}
\hline Year & Count \\
\hline 1980 & 66 \\
1985 & 80 \\
1990 & 236 \\
1995 & 556 \\
2000 & 472 \\
2005 & 583 \\
2010 & 650 \\
2015 & 627
\end{tabular}

Source: https://aib.msu.edu/statistics.asp.

Table A2 The geographic distribution of AIB membership since 1995

\begin{tabular}{|c|c|c|c|c|c|}
\hline Region & North America & Europe & Asian/Pacific & Other & Total \\
\hline 1995 & 1722 & 368 & 495 & 71 & 2656 \\
\hline 1996 & 1621 & 379 & 537 & 78 & 2615 \\
\hline 1997 & 1647 & 383 & 554 & 83 & 2667 \\
\hline 1998 & 1636 & 427 & 486 & 79 & 2628 \\
\hline 1999 & 1619 & 459 & 464 & 80 & 2622 \\
\hline 2000 & 1595 & 513 & 455 & 62 & 2625 \\
\hline 2001 & 1485 & 532 & 492 & 56 & 2565 \\
\hline 2002 & 1480 & 490 & 569 & 62 & 2601 \\
\hline 2003 & 1442 & 553 & 526 & 64 & 2585 \\
\hline 2004 & 1394 & 599 & 515 & 60 & 2568 \\
\hline 2005 & 1493 & 718 & 574 & 71 & 2856 \\
\hline 2006 & 1618 & 810 & 734 & 92 & 3254 \\
\hline 2007 & 1605 & 798 & 824 & 100 & 3327 \\
\hline 2008 & 1590 & 859 & 800 & 134 & 3383 \\
\hline 2009 & 1570 & 856 & 783 & 157 & 3366 \\
\hline 2010 & 1501 & 913 & 789 & 218 & 3421 \\
\hline 2011 & 1409 & 897 & 938 & 247 & 3491 \\
\hline 2012 & 1370 & 916 & 997 & 234 & 3517 \\
\hline 2013 & 1409 & 1011 & 971 & 238 & 3629 \\
\hline 2014 & 1326 & 997 & 964 & 316 & 3603 \\
\hline
\end{tabular}


Table A3 The variation in the number of JIBS articles published over time (or Figure A2 in table format)

\begin{tabular}{lccc}
\hline Year & Article count & Year & Article count \\
\hline 1972 & 10 & 1994 & 34 \\
1973 & 17 & 1995 & 39 \\
1974 & 18 & 1996 & 43 \\
1975 & 15 & 1997 & 31 \\
1976 & 16 & 1998 & 40 \\
1977 & 18 & 2000 & 41 \\
1978 & 33 & 2001 & 41 \\
1979 & 25 & 2002 & 49 \\
1980 & 29 & 2003 & 43 \\
1981 & 28 & 2004 & 40 \\
1982 & 29 & 2005 & 32 \\
1983 & 31 & 2006 & 40 \\
1984 & 41 & 2008 & 49 \\
1985 & 29 & 2009 & 65 \\
1986 & 31 & 2010 & 73 \\
1987 & 20 & 2011 & 77 \\
1988 & 24 & 2012 & 83 \\
1989 & 27 & 2013 & 57 \\
1990 & 31 & 2014 &
\end{tabular}

Table A4 The distribution of various categories for downloaded data from 2004 to 2014

\begin{tabular}{lrrrrrrrrrrr}
\hline & 2004 & 2005 & 2006 & 2007 & 2008 & 2009 & 2010 & 2011 & 2012 & 2013 & 2014 \\
\hline Article & 23 & 34 & 45 & 59 & 64 & 71 & 65 & 44 & 32 & 38 & 52 \\
Commentary & 2 & 0 & 3 & 3 & 1 & 0 & 4 & 1 & 0 & 0 & 0 \\
Essay & 0 & 0 & 1 & 0 & 0 & 0 & 0 & 0 & 0 & 0 & 0 \\
Special Issue Introduction & 1 & 0 & 0 & 0 & 1 & 1 & 3 & 1 & 0 & 0 & 0 \\
Note & 0 & 0 & 0 & 0 & 1 & 3 & 9 & 8 & 4 & 4 & 2 \\
Perspective & 6 & 3 & 1 & 1 & 6 & 2 & 2 & 3 & 0 & 0 & 0 \\
\hline
\end{tabular}

Table A5 The average number of authors per paper per year from 1972 to 2014

\begin{tabular}{|c|c|c|c|c|c|c|}
\hline \multirow[t]{2}{*}{ Year } & \multicolumn{3}{|c|}{ Full sample } & \multicolumn{3}{|c|}{ Excluding outliers } \\
\hline & $\begin{array}{l}\text { Author } \\
\text { count }\end{array}$ & $\begin{array}{l}\text { Article } \\
\text { count }\end{array}$ & $\begin{array}{c}\text { Average author count per } \\
\text { article }\end{array}$ & $\begin{array}{l}\text { Author } \\
\text { count }\end{array}$ & $\begin{array}{l}\text { Article } \\
\text { count }\end{array}$ & $\begin{array}{c}\text { Average author count per } \\
\text { article }\end{array}$ \\
\hline 1972 & 14 & 10 & 1.40 & 14 & 10 & 1.40 \\
\hline 1973 & 19 & 17 & 1.12 & 19 & 17 & 1.12 \\
\hline 1974 & 26 & 18 & 1.44 & 26 & 18 & 1.44 \\
\hline 1975 & 21 & 15 & 1.40 & 21 & 15 & 1.40 \\
\hline 1976 & 24 & 16 & 1.50 & 24 & 16 & 1.50 \\
\hline 1977 & 31 & 18 & 1.72 & 31 & 18 & 1.72 \\
\hline 1978 & 48 & 33 & 1.45 & 48 & 33 & 1.45 \\
\hline 1979 & 44 & 25 & 1.76 & 44 & 25 & 1.76 \\
\hline 1980 & 47 & 29 & 1.62 & 47 & 29 & 1.62 \\
\hline 1981 & 46 & 28 & 1.64 & 46 & 28 & 1.64 \\
\hline 1982 & 47 & 29 & 1.62 & 47 & 29 & 1.62 \\
\hline 1983 & 48 & 31 & 1.55 & 48 & 31 & 1.55 \\
\hline
\end{tabular}


Table A5 (Continued)

\begin{tabular}{|c|c|c|c|c|c|c|}
\hline \multirow[t]{2}{*}{ Year } & \multicolumn{3}{|c|}{ Full sample } & \multicolumn{3}{|c|}{ Excluding outliers } \\
\hline & $\begin{array}{l}\text { Author } \\
\text { count }\end{array}$ & $\begin{array}{l}\text { Article } \\
\text { count }\end{array}$ & $\begin{array}{c}\text { Average author count per } \\
\text { article }\end{array}$ & $\begin{array}{l}\text { Author } \\
\text { count }\end{array}$ & $\begin{array}{l}\text { Article } \\
\text { count }\end{array}$ & $\begin{array}{c}\text { Average author count per } \\
\text { article }\end{array}$ \\
\hline 1984 & 61 & 41 & 1.49 & 61 & 41 & 1.49 \\
\hline 1985 & 46 & 29 & 1.59 & 46 & 29 & 1.59 \\
\hline 1986 & 53 & 31 & 1.71 & 53 & 31 & 1.71 \\
\hline 1987 & 37 & 20 & 1.85 & 37 & 20 & 1.85 \\
\hline 1988 & 36 & 24 & 1.50 & 36 & 24 & 1.50 \\
\hline 1989 & 41 & 27 & 1.52 & 41 & 27 & 1.52 \\
\hline 1990 & 53 & 31 & 1.71 & 53 & 31 & 1.71 \\
\hline 1991 & 59 & 33 & 1.79 & 59 & 33 & 1.79 \\
\hline 1992 & 58 & 31 & 1.87 & 58 & 31 & 1.87 \\
\hline 1993 & 67 & 35 & 1.91 & 67 & 35 & 1.91 \\
\hline 1994 & 62 & 34 & 1.82 & 62 & 34 & 1.82 \\
\hline 1995 & 67 & 39 & 1.72 & 67 & 39 & 1.72 \\
\hline 1996 & 95 & 43 & 2.21 & 95 & 43 & 2.21 \\
\hline 1997 & 68 & 31 & 2.19 & 68 & 31 & 2.19 \\
\hline 1998 & 80 & 40 & 2.00 & 70 & 39 & 1.79 \\
\hline 1999 & 95 & 41 & 2.32 & 95 & 41 & 2.32 \\
\hline 2000 & 92 & 41 & 2.24 & 92 & 41 & 2.24 \\
\hline 2001 & 94 & 49 & 1.92 & 94 & 49 & 1.92 \\
\hline 2002 & 94 & 43 & 2.19 & 94 & 43 & 2.19 \\
\hline 2003 & 87 & 40 & 2.18 & 87 & 40 & 2.18 \\
\hline 2004 & 85 & 32 & 2.66 & 70 & 31 & 2.26 \\
\hline 2005 & 91 & 40 & 2.28 & 91 & 40 & 2.28 \\
\hline 2006 & 152 & 49 & 3.10 & 111 & 48 & 2.31 \\
\hline 2007 & 160 & 65 & 2.46 & 160 & 65 & 2.46 \\
\hline 2008 & 198 & 73 & 2.71 & 198 & 73 & 2.71 \\
\hline 2009 & 235 & 77 & 3.05 & 192 & 76 & 2.53 \\
\hline 2010 & 222 & 83 & 2.67 & 222 & 83 & 2.67 \\
\hline 2011 & 135 & 57 & 2.37 & 135 & 57 & 2.37 \\
\hline 2012 & 117 & 36 & 3.25 & 88 & 35 & 2.51 \\
\hline 2013 & 119 & 42 & 2.83 & 119 & 42 & 2.83 \\
\hline 2014 & 138 & 53 & 2.60 & 138 & 53 & 2.60 \\
\hline
\end{tabular}

Table A6 The percentage of first-time authors from 1995 to 2014

\begin{tabular}{rccccc}
\hline Year & $\begin{array}{c}\text { Author } \\
\text { count }\end{array}$ & $\begin{array}{c}\text { First-time } \\
\text { author count }\end{array}$ & $\begin{array}{c}\text { Percentage of first-time } \\
\text { author count }\end{array}$ & $\begin{array}{c}\text { First-time author count } \\
\text { (excluding outliers) }\end{array}$ & $\begin{array}{c}\text { Percentage of first-time author count } \\
\text { (excluding outliers) }\end{array}$ \\
\hline 1995 & 67 & 41 & 61.19 & 41 & 61.19 \\
1996 & 98 & 68 & 69.39 & 68 & 69.39 \\
1997 & 73 & 43 & 58.90 & 43 & 58.90 \\
1998 & 86 & 48 & 55.81 & 40 & 46.51 \\
1999 & 103 & 68 & 66.02 & 68 & 66.02 \\
2000 & 96 & 67 & 69.79 & 67 & 69.79 \\
2001 & 97 & 61 & 62.89 & 61 & 62.89 \\
2002 & 99 & 49 & 49.49 & 49 & 49.49 \\
2003 & 98 & 42 & 42.86 & 42 & 42.86 \\
2004 & 89 & 51 & 57.30 & 36 & 40.45 \\
2005 & 101 & 58 & 57.43 & 58 & 57.43 \\
2006 & 157 & 106 & 67.52 & 72 & 103 \\
2007 & 173 & 103 & 59.54 & 127 & 45.86 \\
2008 & 216 & 127 & 58.80 & 111 & 59.54 \\
2009 & 252 & 147 & 58.33 & 58.80 \\
\hline
\end{tabular}


Table A6 (Continued)

\begin{tabular}{|c|c|c|c|c|c|}
\hline Year & $\begin{array}{l}\text { Author } \\
\text { count }\end{array}$ & $\begin{array}{l}\text { First-time } \\
\text { author count }\end{array}$ & $\begin{array}{c}\text { Percentage of first-time } \\
\text { author count }\end{array}$ & $\begin{array}{l}\text { First-time author count } \\
\text { (excluding outliers) }\end{array}$ & $\begin{array}{l}\text { Percentage of first-time author count } \\
\text { (excluding outliers) }\end{array}$ \\
\hline 2010 & 237 & 116 & 48.95 & 116 & 48.95 \\
\hline 2011 & 154 & 89 & 57.79 & 89 & 57.79 \\
\hline 2012 & 122 & 92 & 75.41 & 63 & 51.64 \\
\hline 2013 & 131 & 65 & 49.62 & 65 & 49.62 \\
\hline 2014 & 152 & 89 & 58.55 & 89 & 58.55 \\
\hline
\end{tabular}

Table A7a AlB membership information from 1995 to 2014

\begin{tabular}{|c|c|}
\hline Year & AIB membership \\
\hline 1995 & 2656 \\
\hline 1996 & 2615 \\
\hline 1997 & 2667 \\
\hline 1998 & 2628 \\
\hline 1999 & 2622 \\
\hline 2000 & 2625 \\
\hline 2001 & 2565 \\
\hline 2002 & 2601 \\
\hline 2003 & 2585 \\
\hline 2004 & 2568 \\
\hline 2005 & 2856 \\
\hline 2006 & 3254 \\
\hline 2007 & 3327 \\
\hline 2008 & 3383 \\
\hline 2009 & 3366 \\
\hline 2010 & 3421 \\
\hline 2011 & 3491 \\
\hline 2012 & 3517 \\
\hline 2013 & 3629 \\
\hline 2014 & 3603 \\
\hline
\end{tabular}

Table A7b The potential pool of first-time authors from 1995 to 2014

\begin{tabular}{lr}
\hline Year & Potential pool of first-time authors \\
\hline 1995 & 1948 \\
1996 & 1839 \\
1997 & 1848 \\
1998 & 1761 \\
1999 & 1687 \\
2000 & 1623 \\
2001 & 1502 \\
2002 & 1489 \\
2003 & 1431 \\
2004 & 1363 \\
2005 & 1593 \\
2006 & 1885 \\
2007 & 1855 \\
2008 & 1784 \\
2009 & 1620 \\
\end{tabular}




\begin{tabular}{lr}
\hline Year & Potential pool of first-time authors \\
\hline 2011 & 1540 \\
2012 & 1474 \\
2013 & 1521 \\
2014 & 1406 \\
\hline
\end{tabular}

Table A8 The percentage of JIBS authors that are AIB members

\begin{tabular}{lr}
\hline Year & Percentage of JIBS authors who are AIB members \\
\hline 2009 & 50.25 \\
2010 & 46.18 \\
2011 & 46.42 \\
2012 & 65.87 \\
2013 & 50.81 \\
\hline
\end{tabular}

Table A9 The percentage of authors with prior publications

\begin{tabular}{|c|c|c|c|}
\hline Year & $\begin{array}{l}\text { Author count (excluding } \\
\text { outliers) }\end{array}$ & $\begin{array}{l}\text { Authors with at least three JIBS } \\
\text { publications }\end{array}$ & $\begin{array}{c}\text { Percentage of authors with at least three JIBS } \\
\text { publications }\end{array}$ \\
\hline 1981 & 46 & 4 & 8.70 \\
\hline 1982 & 47 & 2 & 4.26 \\
\hline 1983 & 48 & 2 & 4.17 \\
\hline 1984 & 61 & 7 & 11.48 \\
\hline 1985 & 46 & 2 & 4.35 \\
\hline 1986 & 53 & 4 & 7.55 \\
\hline 1987 & 37 & 2 & 5.41 \\
\hline 1988 & 36 & 5 & 13.89 \\
\hline 1989 & 41 & 6 & 14.63 \\
\hline 1990 & 53 & 5 & 9.43 \\
\hline 1991 & 59 & 5 & 8.47 \\
\hline 1992 & 58 & 10 & 17.24 \\
\hline 1993 & 67 & 5 & 7.46 \\
\hline 1994 & 62 & 8 & 12.90 \\
\hline 1995 & 67 & 8 & 11.94 \\
\hline 1996 & 95 & 5 & 5.26 \\
\hline 1997 & 68 & 4 & 5.88 \\
\hline 1998 & 80 & 15 & 18.75 \\
\hline 1999 & 95 & 9 & 9.47 \\
\hline 2000 & 92 & 10 & 10.87 \\
\hline 2001 & 94 & 12 & 12.77 \\
\hline 2002 & 94 & 24 & 25.53 \\
\hline 2003 & 87 & 17 & 19.54 \\
\hline 2004 & 70 & 13 & 18.57 \\
\hline 2005 & 91 & 10 & 10.99 \\
\hline 2006 & 111 & 11 & 9.91 \\
\hline 2007 & 160 & 23 & 14.38 \\
\hline 2008 & 198 & 37 & 18.69 \\
\hline 2009 & 192 & 25 & 13.02 \\
\hline 2010 & 222 & 40 & 18.02 \\
\hline 2011 & 135 & 18 & 13.33 \\
\hline 2012 & 88 & 13 & 14.77 \\
\hline 2013 & 119 & 20 & 16.81 \\
\hline 2014 & 138 & 22 & 15.94 \\
\hline
\end{tabular}


Table A10 The average number of countries of residence of authors per paper per year

\begin{tabular}{|c|c|c|}
\hline Year & Average for all articles & Average for all articles (excluding outliers) \\
\hline 1972 & 1.00 & 1.00 \\
\hline 1973 & 1.00 & 1.00 \\
\hline 1975 & 1.00 & 1.00 \\
\hline 1976 & 1.06 & 1.06 \\
\hline 1977 & 1.11 & 1.11 \\
\hline 1978 & 1.09 & 1.09 \\
\hline 1979 & 1.16 & 1.16 \\
\hline 1980 & 1.14 & 1.14 \\
\hline 1981 & 1.04 & 1.04 \\
\hline 1982 & 1.10 & 1.10 \\
\hline 1983 & 1.16 & 1.16 \\
\hline 1984 & 1.10 & 1.10 \\
\hline 1985 & 1.10 & 1.10 \\
\hline 1986 & 1.10 & 1.10 \\
\hline 1987 & 1.20 & 1.20 \\
\hline 1988 & 1.17 & 1.17 \\
\hline 1989 & 1.26 & 1.26 \\
\hline 1990 & 1.23 & 1.23 \\
\hline 1991 & 1.15 & 1.15 \\
\hline 1992 & 1.26 & 1.26 \\
\hline 1993 & 1.14 & 1.14 \\
\hline 1994 & 1.18 & 1.18 \\
\hline 1995 & 1.28 & 1.28 \\
\hline 1996 & 1.51 & 1.51 \\
\hline 1997 & 1.42 & 1.42 \\
\hline 1998 & 1.28 & 1.21 \\
\hline 1999 & 1.51 & 1.51 \\
\hline 2000 & 1.39 & 1.39 \\
\hline 2001 & 1.27 & 1.27 \\
\hline 2002 & 1.35 & 1.35 \\
\hline 2003 & 1.60 & 1.60 \\
\hline 2004 & 1.59 & 1.32 \\
\hline 2005 & 1.45 & 1.45 \\
\hline 2006 & 1.59 & 1.29 \\
\hline 2007 & 1.66 & 1.66 \\
\hline 2008 & 1.59 & 1.59 \\
\hline 2009 & 1.95 & 1.64 \\
\hline 2010 & 1.77 & 1.77 \\
\hline 2011 & 1.79 & 1.79 \\
\hline 2012 & 2.44 & 1.80 \\
\hline 2013 & 2.00 & 2.00 \\
\hline 2014 & 1.89 & 1.89 \\
\hline
\end{tabular}


Table A11 The percentage of authors from North America, Europe, Asia-Pacific and Other regions from 1972 to 2014

\begin{tabular}{|c|c|c|c|c|}
\hline Year & North America & Europe & Asia Pacific & Other \\
\hline 1972 & 92.86 & 0.00 & 0.00 & 0.00 \\
\hline 1973 & 100.00 & 0.00 & 0.00 & 0.00 \\
\hline 1975 & 95.24 & 4.76 & 0.00 & 0.00 \\
\hline 1976 & 83.33 & 16.67 & 0.00 & 0.00 \\
\hline 1977 & 87.10 & 9.68 & 0.00 & 3.23 \\
\hline 1978 & 79.17 & 10.42 & 4.17 & 6.25 \\
\hline 1979 & 84.09 & 9.09 & 2.27 & 4.55 \\
\hline 1980 & 87.23 & 8.51 & 2.13 & 2.13 \\
\hline 1981 & 91.30 & 8.70 & 0.00 & 0.00 \\
\hline 1982 & 85.42 & 10.42 & 4.17 & 0.00 \\
\hline 1983 & 81.25 & 4.17 & 14.58 & 0.00 \\
\hline 1984 & 86.89 & 8.20 & 3.28 & 0.00 \\
\hline 1985 & 86.96 & 8.70 & 4.35 & 0.00 \\
\hline 1986 & 88.68 & 5.66 & 5.66 & 0.00 \\
\hline 1987 & 84.21 & 5.26 & 5.26 & 5.26 \\
\hline 1988 & 72.97 & 24.32 & 2.70 & 0.00 \\
\hline 1989 & 80.95 & 14.29 & 2.38 & 2.38 \\
\hline 1990 & 71.70 & 18.87 & 9.43 & 0.00 \\
\hline 1991 & 76.27 & 18.64 & 3.39 & 1.69 \\
\hline 1992 & 71.19 & 20.34 & 8.47 & 0.00 \\
\hline 1993 & 74.63 & 7.46 & 16.42 & 1.49 \\
\hline 1994 & 92.31 & 4.62 & 3.08 & 0.00 \\
\hline 1995 & 65.67 & 20.90 & 13.43 & 0.00 \\
\hline 1996 & 55.10 & 31.63 & 13.27 & 0.00 \\
\hline 1997 & 58.90 & 19.18 & 21.92 & 0.00 \\
\hline 1998 & 72.09 & 15.12 & 12.79 & 0.00 \\
\hline 1999 & 65.05 & 14.56 & 17.48 & 2.91 \\
\hline 2000 & 54.17 & 28.13 & 17.71 & 0.00 \\
\hline 2001 & 62.89 & 25.77 & 11.34 & 0.00 \\
\hline 2002 & 51.52 & 24.24 & 23.23 & 0.00 \\
\hline 2003 & 52.04 & 34.69 & 13.27 & 0.00 \\
\hline 2004 & 53.93 & 24.72 & 21.35 & 0.00 \\
\hline 2005 & 59.41 & 23.76 & 15.84 & 0.99 \\
\hline 2006 & 54.78 & 20.38 & 21.66 & 3.18 \\
\hline 2007 & 42.20 & 33.53 & 22.54 & 1.73 \\
\hline 2008 & 53.24 & 26.39 & 20.37 & 0.00 \\
\hline 2009 & 46.83 & 31.75 & 19.44 & 1.98 \\
\hline 2010 & 50.21 & 29.96 & 19.41 & 0.42 \\
\hline 2011 & 44.16 & 33.77 & 21.43 & 0.65 \\
\hline 2012 & 33.61 & 41.80 & 21.31 & 3.28 \\
\hline 2013 & 44.27 & 29.77 & 25.95 & 0.00 \\
\hline 2014 & 37.50 & 42.11 & 19.74 & 0.66 \\
\hline
\end{tabular}


Table A12 The percentage of business schools by region for 2013-2016 (data for other years was not available)

\begin{tabular}{lrrrr}
\hline Region & 2013 & 2014 & 2015 & 2016 \\
\hline Asia-Pacific & $14.14 \%$ & $14.14 \%$ & $15.15 \%$ & $16.16 \%$ \\
Europe & $25.25 \%$ & $27.27 \%$ & $27.27 \%$ & $29.29 \%$ \\
North America & $56.57 \%$ & $55.56 \%$ & $56.57 \%$ & $52.53 \%$ \\
Other & $4.00 \%$ & $3.00 \%$ & $1.00 \%$ & $3.00 \%$ \\
\hline
\end{tabular}

Source: Financial Times MBA ranking for Top 100 Business Schools

Table A13 The regional distribution of first-time authors

\begin{tabular}{lcrr}
\hline Year & North America & Europe & Asia Pacific \\
\hline 1995 & 27 & 8 & 6 \\
1996 & 36 & 25 & 7 \\
1997 & 23 & 9 & 9 \\
1998 & 35 & 4 & 13 \\
1999 & 44 & 9 & 12 \\
2000 & 36 & 19 & 10 \\
2001 & 34 & 17 & 12 \\
2002 & 25 & 11 & 8 \\
2003 & 21 & 13 & 16 \\
2004 & 23 & 12 & 12 \\
2005 & 29 & 16 & 24 \\
2006 & 54 & 24 & 26 \\
2007 & 45 & 31 & 28 \\
2008 & 60 & 39 & \\
2009 & 69 & 42 & 27 \\
2010 & 58 & 30 & 16 \\
2011 & 39 & 33 & 20 \\
2012 & 28 & 40 & 19 \\
2013 & 28 & 34 & 15 \\
\hline
\end{tabular}

Table A14 Job-seeking migrants by country of origin and country of residence

\begin{tabular}{|c|c|c|c|c|c|c|c|c|c|c|}
\hline \multirow[t]{2}{*}{ Country of origin } & \multicolumn{10}{|c|}{ Country of residence } \\
\hline & Australia & Belgium & Canada & China & Denmark & Finland & France & Germany & Ireland & Italy \\
\hline USA & 0 & 0 & 3 & 2 & 0 & 1 & 1 & 0 & 0 & 0 \\
\hline Canada & 0 & 0 & 0 & 0 & 0 & 0 & 0 & 0 & 0 & 0 \\
\hline China & 0 & 0 & 0 & 0 & 0 & 0 & 0 & 0 & 0 & 0 \\
\hline Finland & 0 & 0 & 0 & 0 & 0 & 0 & 0 & 0 & 0 & 0 \\
\hline Germany & 0 & 1 & 0 & 0 & 1 & 0 & 1 & 0 & 0 & 0 \\
\hline Russia & 0 & 0 & 0 & 0 & 0 & 0 & 0 & 0 & 0 & 0 \\
\hline Italy & 0 & 0 & 0 & 0 & 0 & 0 & 0 & 0 & 0 & 0 \\
\hline Austria & 0 & 0 & 0 & 0 & 0 & 0 & 0 & 2 & 0 & 0 \\
\hline Belgium & 0 & 0 & 2 & 0 & 0 & 0 & 0 & 0 & 0 & 0 \\
\hline Netherlands & 0 & 2 & 0 & 0 & 0 & 0 & 1 & 0 & 0 & 0 \\
\hline Sweden & 1 & 0 & 0 & 0 & 1 & 0 & 0 & 0 & 0 & 0 \\
\hline UK & 0 & 0 & 0 & 0 & 0 & 0 & 1 & 0 & 0 & 0 \\
\hline Switzerland & 0 & 0 & 1 & 0 & 0 & 0 & 0 & 0 & 0 & 0 \\
\hline Australia & 0 & 0 & 0 & 0 & 0 & 0 & 0 & 0 & 1 & 0 \\
\hline Denmark & 0 & 0 & 0 & 0 & 0 & 0 & 0 & 0 & 0 & 1 \\
\hline France & 0 & 1 & 0 & 0 & 0 & 0 & 0 & 0 & 0 & 0 \\
\hline
\end{tabular}


Table A14 (Continued)

\begin{tabular}{|c|c|c|c|c|c|c|c|c|c|c|c|}
\hline \multirow[t]{2}{*}{ Country of origin } & \multicolumn{11}{|c|}{ Country of residence } \\
\hline & Australia & Belgium & Canada & China & Denmark & Finland & France & Ger & any & Ireland & Italy \\
\hline Greece & 0 & 0 & 1 & 0 & 0 & 0 & 0 & & & 0 & 0 \\
\hline India & 0 & 0 & 1 & 0 & 0 & 0 & 0 & & & 0 & 0 \\
\hline Portugal & 0 & 0 & 0 & 0 & 0 & 0 & 0 & & & 0 & 0 \\
\hline Slovenia & 0 & 0 & 0 & 0 & 1 & 0 & 0 & & & 0 & 0 \\
\hline Spain & 0 & 0 & 0 & 0 & 0 & 0 & 0 & & & 0 & 0 \\
\hline Sri Lanka & 0 & 0 & 0 & 0 & 0 & 0 & 0 & & & 0 & 0 \\
\hline Turkey & 0 & 0 & 0 & 0 & 0 & 0 & 0 & & & 0 & 0 \\
\hline \multirow[t]{2}{*}{ Country of origin } & \multicolumn{10}{|c|}{ Country of residence } & \multirow[t]{2}{*}{ Tota } \\
\hline & Japan & Netherlands & Peru & Singapore & Switz & fland & Taiwan & UAE & UK & USA & \\
\hline USA & 0 & 0 & 0 & 1 & & & 0 & 0 & 2 & 0 & 10 \\
\hline Canada & 0 & 0 & 0 & 0 & & & 0 & 0 & 0 & 4 & 5 \\
\hline China & 0 & 0 & 0 & 0 & & & 1 & 0 & 0 & 4 & 5 \\
\hline Finland & 2 & 0 & 0 & 0 & & & 0 & 0 & 1 & 1 & 5 \\
\hline Germany & 0 & 0 & 0 & 0 & & & 0 & 0 & 1 & 0 & 5 \\
\hline Russia & 0 & 0 & 0 & 0 & & & 0 & 0 & 4 & 1 & 5 \\
\hline Italy & 0 & 0 & 0 & 0 & & & 0 & 0 & 2 & 2 & 4 \\
\hline Austria & 0 & 0 & 0 & 0 & & & 0 & 0 & 1 & 0 & 3 \\
\hline Belgium & 0 & 0 & 0 & 0 & & & 0 & 0 & 0 & 0 & 3 \\
\hline Netherlands & 0 & 0 & 0 & 0 & & & 0 & 0 & 0 & 0 & 3 \\
\hline Sweden & 1 & 0 & 0 & 0 & & & 0 & 0 & 0 & 0 & 3 \\
\hline UK & 0 & 0 & 0 & 0 & & & 0 & 0 & 0 & 2 & 3 \\
\hline Switzerland & 0 & 1 & 0 & 0 & & & 0 & 0 & 0 & 0 & 2 \\
\hline Australia & 0 & 0 & 0 & 0 & & & 0 & 0 & 0 & 0 & 1 \\
\hline Denmark & 0 & 0 & 0 & 0 & & & 0 & 0 & 0 & 0 & 1 \\
\hline France & 0 & 0 & 0 & 0 & & & 0 & 0 & 0 & 0 & 1 \\
\hline Greece & 0 & 0 & 0 & 0 & & & 0 & 0 & 0 & 0 & 1 \\
\hline India & 0 & 0 & 0 & 0 & & & 0 & 0 & 0 & 0 & 1 \\
\hline Portugal & 0 & 1 & 0 & 0 & & & 0 & 0 & 0 & 0 & 1 \\
\hline Slovenia & 0 & 0 & 0 & 0 & & & 0 & 0 & 0 & 0 & 1 \\
\hline Spain & 0 & 0 & 1 & 0 & & & 0 & 0 & 0 & 0 & 1 \\
\hline Sri Lanka & 0 & 0 & 0 & 0 & & & 0 & 1 & 0 & 0 & 1 \\
\hline Turkey & 0 & 0 & 0 & 0 & & & 0 & 0 & 0 & 1 & 1 \\
\hline
\end{tabular}

Table A15 Nomads by country of origin and country of residence

\begin{tabular}{lccccccccccc}
\hline $\begin{array}{l}\text { Country of } \\
\text { origin }\end{array}$ & Australia & Austria & Canada & China & $\begin{array}{c}\text { Costa } \\
\text { Rica }\end{array}$ & Denmark & France & Israel & Malaysia & $\begin{array}{c}\text { Netherlands } \\
\text { Zealand }\end{array}$ \\
\hline China & 0 & 0 & 12 & 0 & 0 & 0 & 0 & 0 & 1 & 1 & 0 \\
India & 2 & 0 & 8 & 1 & 0 & 0 & 1 & 0 & 0 & 1 & 0 \\
South Korea & 0 & 0 & 3 & 4 & 0 & 0 & 0 & 0 & 0 & 0 & 0 \\
France & 0 & 0 & 1 & 0 & 0 & 0 & 0 & 0 & 0 & 9 & 0 \\
Germany & 2 & 0 & 1 & 1 & 0 & 1 & 0 & 0 & 0 & 0 & 1 \\
UK & 0 & 0 & 2 & 0 & 0 & 0 & 0 & 0 & 0 & 0 & 0 \\
Russia & 0 & 0 & 1 & 0 & 0 & 0 & 0 & 0 & 0 & 4 & 0 \\
Taiwan & 0 & 0 & 3 & 0 & 0 & 0 & 0 & 0 & 0 & 0 \\
Tunisia & 0 & 0 & 0 & 1 & 0 & 0 & 0 & 0 & 0 & 0 & 0 \\
Turkey & 0 & 0 & 2 & 0 & 0 & 0 & 0 & 0 & 0 & 0 & 0 \\
Belgium & 0 & 0 & 1 & 0 & 0 & 0 & 0 & 0 & 0 & 0 \\
Italy & 0 & 0 & 0 & 0 & 0 & 0 & 0 & 0 & 0 & 2 \\
Japan & 0 & 0 & 0 & 1 & 0 & 0 & 0 & 0 & 0 & 0 \\
Netherlands & 3 & 0 & 0 & 0 & 0 & 0 & 0 & 0 & 0 & 0 \\
\hline
\end{tabular}


Table A15 (Continued)

\begin{tabular}{|c|c|c|c|c|c|c|c|c|c|c|c|c|c|}
\hline $\begin{array}{l}\text { Country of } \\
\text { origin }\end{array}$ & Australia & Austria & Canada & China & $\begin{array}{l}\text { Costa } \\
\text { Rica }\end{array}$ & Denmark & France & Israel & Malaysia & \multicolumn{2}{|c|}{ Netherlands } & \multicolumn{2}{|c|}{$\begin{array}{c}\text { New } \\
\text { Zealand }\end{array}$} \\
\hline New Zealand & 0 & 0 & 0 & 3 & 0 & 0 & 0 & 0 & 0 & 0 & & 0 & \\
\hline Norway & 0 & 0 & 3 & 0 & 0 & 0 & 0 & 0 & 0 & 0 & & 0 & \\
\hline Romania & 1 & 1 & 0 & 0 & 0 & 0 & 0 & 0 & 0 & 0 & & 0 & \\
\hline South Africa & 0 & 0 & 1 & 0 & 0 & 0 & 0 & 2 & 0 & 0 & & 0 & \\
\hline Greece & 0 & 1 & 0 & 0 & 0 & 0 & 0 & 0 & 0 & 0 & & 0 & \\
\hline Sri Lanka & 0 & 0 & 2 & 0 & 0 & 0 & 0 & 0 & 0 & 0 & & 0 & \\
\hline USA & 0 & 0 & 0 & 1 & 0 & 0 & 0 & 0 & 0 & 0 & & 0 & \\
\hline Argentina & 1 & 0 & 0 & 0 & 0 & 0 & 0 & 0 & 0 & 0 & & 0 & \\
\hline Brazil & 1 & 0 & 0 & 0 & 0 & 0 & 0 & 0 & 0 & 0 & & 0 & \\
\hline Bulgaria & 0 & 0 & 0 & 0 & 0 & 0 & 0 & 0 & 0 & 0 & & 1 & \\
\hline Canada & 0 & 0 & 0 & 1 & 0 & 0 & 0 & 0 & 0 & 0 & & 0 & \\
\hline Finland & 0 & 0 & 0 & 0 & 0 & 0 & 0 & 0 & 0 & 1 & & 0 & \\
\hline Guatemala & 0 & 0 & 0 & 0 & 1 & 0 & 0 & 0 & 0 & 0 & & 0 & \\
\hline Indonesia & 1 & 0 & 0 & 0 & 0 & 0 & 0 & 0 & 0 & 0 & & 0 & \\
\hline Iran & 1 & 0 & 0 & 0 & 0 & 0 & 0 & 0 & 0 & 0 & & 0 & \\
\hline Israel & 0 & 0 & 0 & 0 & 0 & 0 & 0 & 0 & 0 & 0 & & 0 & \\
\hline Malaysia & 0 & 0 & 0 & 0 & 0 & 0 & 0 & 0 & 0 & 0 & & 0 & \\
\hline Mauritius & 0 & 0 & 0 & 0 & 0 & 0 & 0 & 0 & 0 & 0 & & 0 & \\
\hline Nepal & 0 & 0 & 1 & 0 & 0 & 0 & 0 & 0 & 0 & 0 & & 0 & \\
\hline Pakistan & 0 & 0 & 0 & 0 & 0 & 0 & 0 & 0 & 0 & 0 & & 0 & \\
\hline Portugal & 0 & 0 & 0 & 0 & 0 & 0 & 0 & 0 & 0 & 0 & & 0 & \\
\hline Tanzania & 0 & 0 & 0 & 0 & 0 & 0 & 0 & 0 & 0 & 0 & & 0 & \\
\hline Thailand & 0 & 0 & 0 & 1 & 0 & 0 & 0 & 0 & 0 & 0 & & 0 & \\
\hline Ukraine & 0 & 0 & 0 & 0 & 0 & 0 & 0 & 0 & 0 & 0 & & 0 & \\
\hline Country of origin & Russia & South & Arabia & Singapore & Korea & Spain & Switzer & land & Taiwan & UAE & UK & USA & Total \\
\hline China & 1 & 0 & & 3 & 1 & 0 & 0 & & 1 & 1 & 0 & 1 & 21 \\
\hline India & 0 & 0 & & 1 & 0 & 0 & 0 & & 0 & 0 & 2 & 5 & 21 \\
\hline South Korea & 0 & 0 & & 5 & 0 & 0 & 0 & & 0 & 0 & 0 & 1 & 13 \\
\hline France & 0 & 0 & & 0 & 0 & 0 & 1 & & 0 & 0 & 0 & 0 & 11 \\
\hline Germany & 0 & 0 & & 2 & 0 & 2 & 0 & & 0 & 0 & 0 & 1 & 11 \\
\hline UK & 0 & 0 & & 5 & 0 & 0 & 0 & & 0 & 0 & 0 & 1 & 8 \\
\hline Russia & 0 & 0 & & 0 & 0 & 0 & 0 & & 0 & 0 & 0 & 0 & 6 \\
\hline Taiwan & 0 & 0 & & 2 & 0 & 0 & 0 & & 0 & 0 & 0 & 0 & 5 \\
\hline Tunisia & 0 & 1 & & 0 & 0 & 0 & 0 & & 0 & 0 & 0 & 2 & 5 \\
\hline Turkey & 0 & 0 & & 1 & 0 & 0 & 0 & & 0 & 0 & 0 & 1 & 4 \\
\hline Belgium & 0 & 0 & & 2 & 0 & 0 & 0 & & 0 & 0 & 0 & 0 & 3 \\
\hline Italy & 0 & 0 & & 0 & 0 & 0 & 0 & & 0 & 0 & 0 & 1 & 3 \\
\hline Japan & 0 & 0 & & 2 & 0 & 0 & 0 & & 0 & 0 & 0 & 0 & 3 \\
\hline Netherlands & 0 & 0 & & 0 & 0 & 0 & 0 & & 0 & 0 & 0 & 0 & 3 \\
\hline New Zealand & 0 & 0 & & 0 & 0 & 0 & 0 & & 0 & 0 & 0 & 0 & 3 \\
\hline Norway & 0 & 0 & & 0 & 0 & 0 & 0 & & 0 & 0 & 0 & 0 & 3 \\
\hline Romania & 0 & 0 & & 0 & 0 & 0 & 0 & & 0 & 0 & 1 & 0 & 3 \\
\hline South Africa & 0 & 0 & & 0 & 0 & 0 & 0 & & 0 & 0 & 0 & 0 & 3 \\
\hline Greece & 0 & 0 & & 0 & 0 & 0 & 0 & & 0 & 0 & 1 & 0 & 2 \\
\hline Sri Lanka & 0 & 0 & & 0 & 0 & 0 & 0 & & 0 & 0 & 0 & 0 & 2 \\
\hline USA & 0 & 0 & & 1 & 0 & 0 & 0 & & 0 & 0 & 0 & 0 & 2 \\
\hline Argentina & 0 & 0 & & 0 & 0 & 0 & 0 & & 0 & 0 & 0 & 0 & 1 \\
\hline Brazil & 0 & 0 & & 0 & 0 & 0 & 0 & & 0 & 0 & 0 & 0 & 1 \\
\hline Bulgaria & 0 & 0 & & 0 & 0 & 0 & 0 & & 0 & 0 & 0 & 0 & 1 \\
\hline Canada & 0 & 0 & & 0 & 0 & 0 & 0 & & 0 & 0 & 0 & 0 & 1 \\
\hline Finland & 0 & 0 & & 0 & 0 & 0 & 0 & & 0 & 0 & 0 & 0 & 1 \\
\hline Guatemala & 0 & 0 & & 0 & 0 & 0 & 0 & & 0 & 0 & 0 & 0 & 1 \\
\hline Indonesia & 0 & 0 & & 0 & 0 & 0 & 0 & & 0 & 0 & 0 & 0 & 1 \\
\hline
\end{tabular}


Table A15 (Continued)

\begin{tabular}{|c|c|c|c|c|c|c|c|c|c|c|c|}
\hline Country of origin & Russia & South Arabia & Singapore & Korea & Spain & Switzerland & Taiwan & UAE & UK & USA & Tota \\
\hline Iran & 0 & 0 & 0 & 0 & 0 & 0 & 0 & 0 & 0 & 0 & 1 \\
\hline Israel & 0 & 0 & 0 & 0 & 0 & 0 & 0 & 0 & 0 & 1 & 1 \\
\hline Malaysia & 0 & 0 & 1 & 0 & 0 & 0 & 0 & 0 & 0 & 0 & 1 \\
\hline Mauritius & 0 & 0 & 0 & 0 & 0 & 0 & 0 & 0 & 1 & 0 & 1 \\
\hline Nepal & 0 & 0 & 0 & 0 & 0 & 0 & 0 & 0 & 0 & 0 & 1 \\
\hline Pakistan & 0 & 0 & 0 & 0 & 0 & 0 & 0 & 0 & 1 & 0 & 1 \\
\hline Portugal & 0 & 0 & 0 & 0 & 0 & 1 & 0 & 0 & 0 & 0 & 1 \\
\hline Tanzania & 0 & 0 & 0 & 0 & 0 & 0 & 0 & 0 & 0 & 1 & 1 \\
\hline Thailand & 0 & 0 & 0 & 0 & 0 & 0 & 0 & 0 & 0 & 0 & 1 \\
\hline Ukraine & 0 & 0 & 0 & 0 & 0 & 0 & 0 & 0 & 0 & 1 & 1 \\
\hline
\end{tabular}

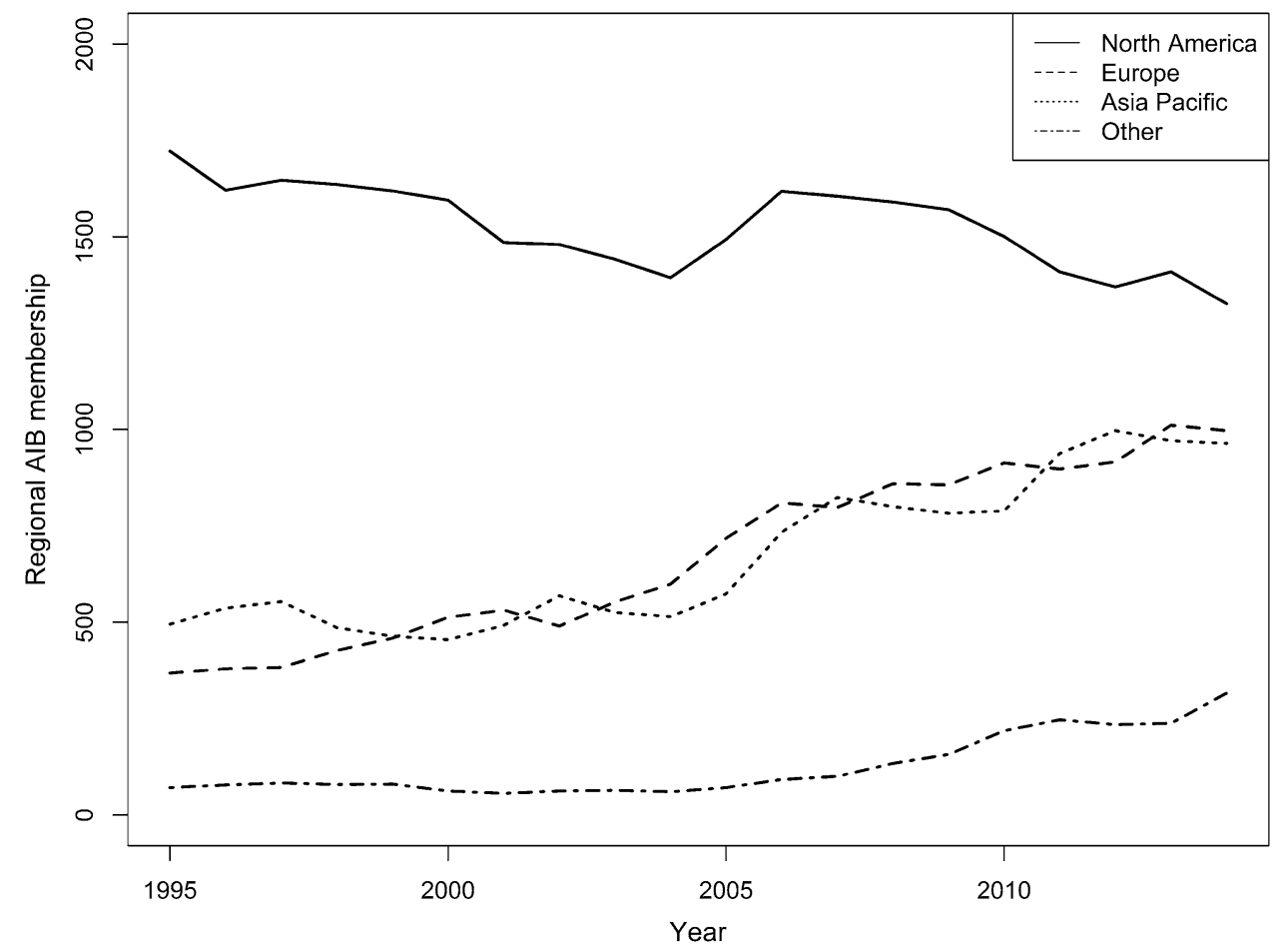

Figure A1 The increased geographic dispersion in AIB membership since 1995. Source: Academy of International Business. 


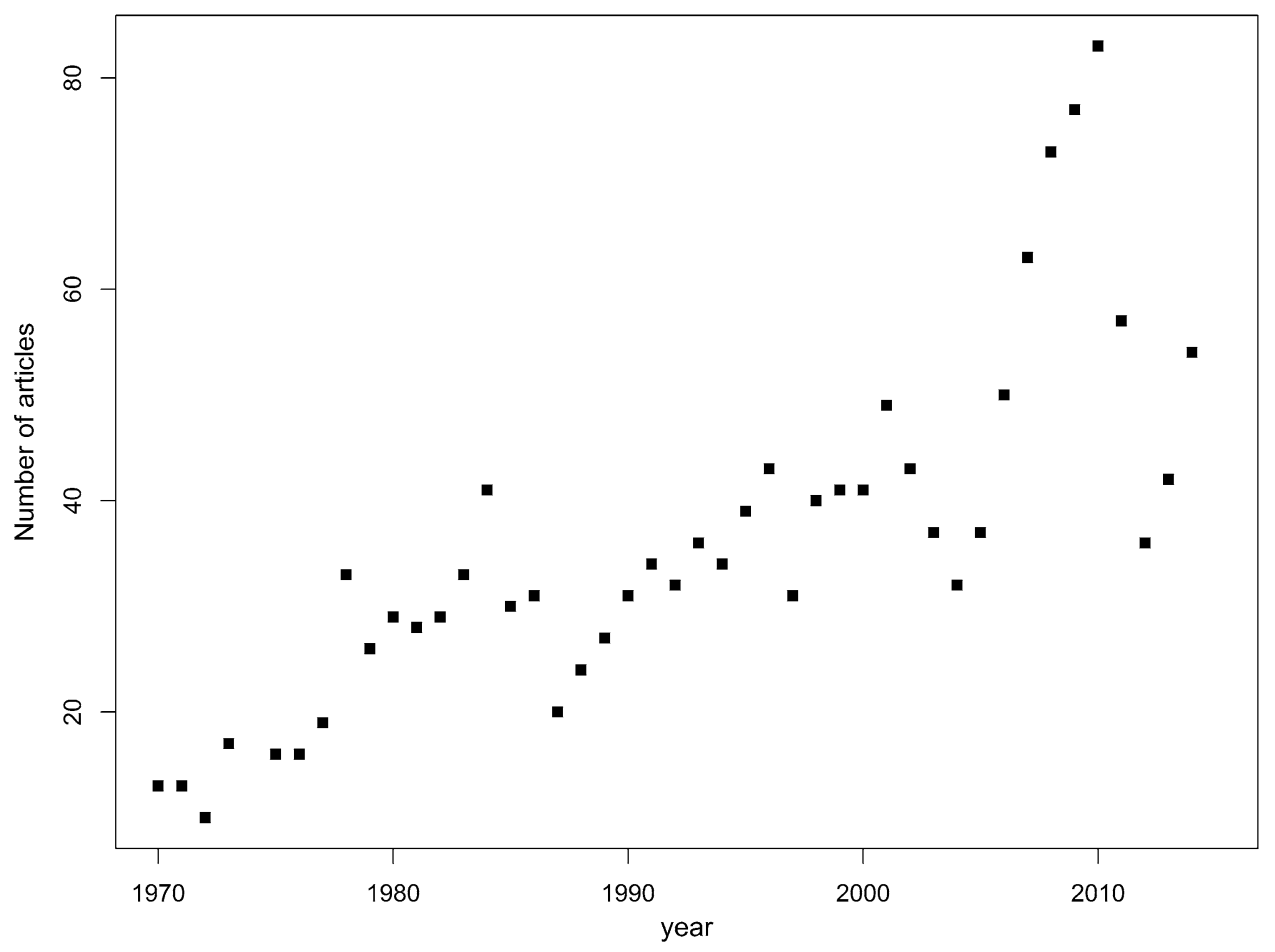

Figure A2 The number of articles published in JIBS from 1970 to 2014 . Note that these include commentaries, essays, introduction to special issues, notes and perspective articles. Source: JIBS archives. 